\title{
REMOÇÃO DA ADSTRINGÊNCIA E ARMAZENAMENTO REFRIGERADO DE FRUTOS DE CAQUIZEIRO \\ (Diospyros kaki L.) cv. GIOMBO
}

\author{
LUCIMARA ROGÉRIA ANTONIOLLI \\ Engenheiro Agrônomo
}

Orientador: Prof. Dr. PAULO ROBERTO DE CAMARGO E CASTRO

Dissertação apresentada à Escola Superior de Agricultura "Luiz de Queiroz", Universidade de São Paulo, para obtenção do título de Mestre em Ciências, Área de Concentração: Fisiologia e Bioquímica de Plantas.

PIRACICABA

Estado de São Paulo - Brasil

Junho - 1999 
Aos meus pais, José e Nair, pelo exemplo de vida.. À minha avó Maria por todo o carinho, dedico. 


\section{AGRADECIMENTOS}

Ao Prof. Dr. Paulo Roberto de Camargo e Castro pela orientação, amizade e incentivo.

Ao amigo e colega do Curso de Pós-Graduação Ricardo A. Kluge pela incomparável colaboração no planejamento e execução do experimento, bem como nas sugestões e revisão do trabalho.

Ao Prof. Dr. João Alexio Scarpare Filho do Departamento de Produção Vegetal da ESALQ pelo auxílio no planejamento e viabilização do experimento, bem como pelas sugestões como membro da pré-banca.

Ao Engenheiro Agrônomo e Consultor em Fruticultura Theodorus A. J. Daamen pelo fornecimento dos frutos.

Ao Departamento de Química da ESALQ, representado pelo Prof. Dr. Luiz Carlos Basso pela concessão de utilização dos equipamentos e dependências do laboratório, e ao funcionário Luís Lucatti ("Cometa") pela sua disponibilidade e amizade.

Ao Clóvis D. Fernandes e Francisco C. Antoniolli, funcionários do Departamento de Ciências Biológicas da ESALQ, pelo grande auxílio e agradável convivio.

Ao Prof. Dr. Ricardo Ferraz de Oliveira do Departamento de Ciências Biológicas da ESALQ e ao Sr. Henrique Figueira pela revisão do Summary.

Ao amigo e colega do Curso de Pós-Graduação Paulo S. R. de Araújo pelas sugestões e revisão do trabalho.

Aos membros da pré-banca, Prof. Dr. João Domingos Rodrigues e Prof. Dr. José Fernando Durigan, pelas sugestões e críticas ao trabalho.

À Coordenação do Curso de Pós-Graduação em Fisiologia e Bioquímica de Plantas, por ter possibilitado a realização do presente trabalho. 
Aos professores e funcionários do Departamento de Ciências Biológicas da ESALQ pela amizade e pelos auxílios prestados.

A todos aqueles que de uma forma ou outra contribuiram para a conclusão deste trabalho.

À CAPES pela bolsa concedida.

Aos meus pais que possivelmente abdicaram de alguns sonhos para que eu pudesse realizar os meus...

À toda minha família que incentivou e apoiou nos momentos mais dificeis.

Aos amigos do Curso de Pós-Graduação que estiveram presentes em todos os momentos...

A DEUS que me permitiu chegar até aqui... 


\section{SUMÁRIO}

Página

LISTA DE FIGURAS ...................................................................... vii

LISTA DE TABELAS....................................................................... ix

LISTA DE ABREVIATURAS E SÍMBOLOS ..........................................

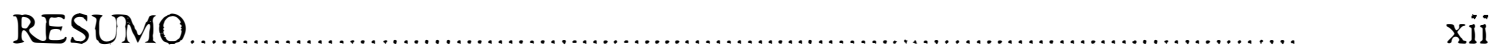

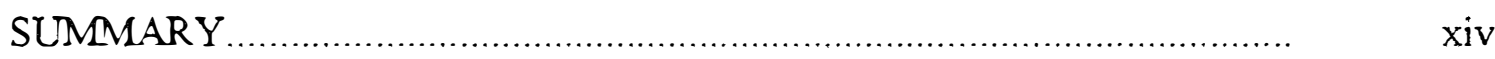

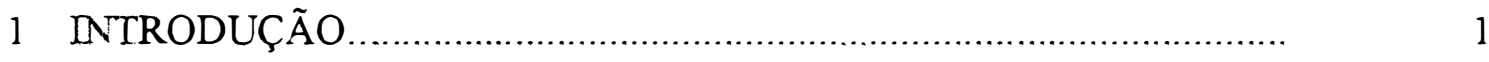

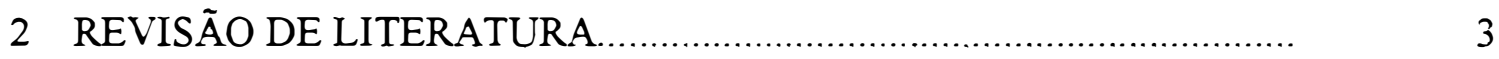

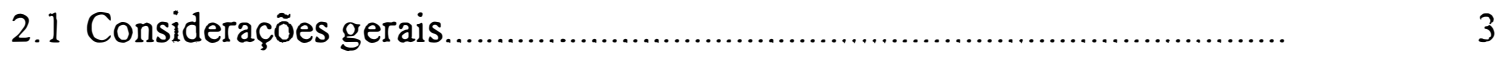

2.2 Maturação, amadurecimento e senescência.............................................. 5

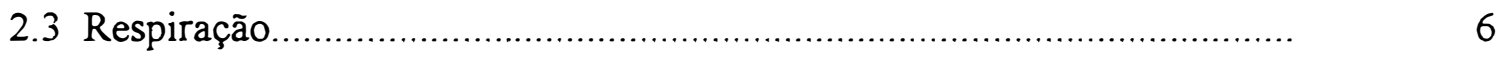

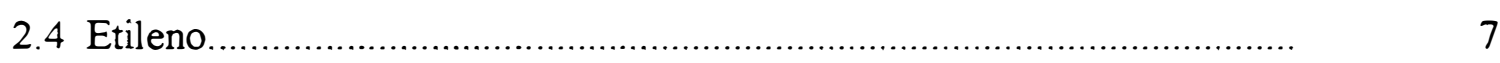

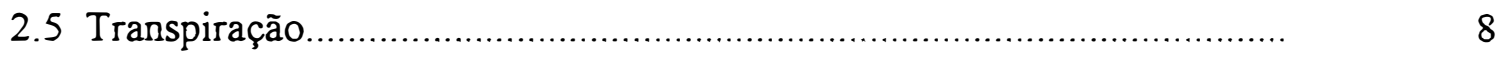

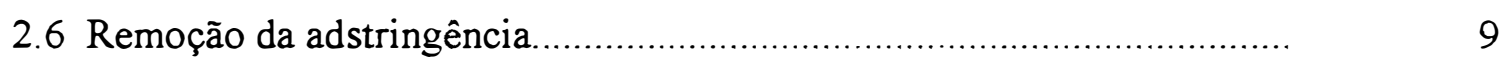

2.7 Armazenamento refrigerado e utilização de embalagem.......................... 14

3 REMOÇÃO DA ADSTRINGÊNCIA DE FRUTOS DE CAQUIZEIRO 'GIOMBO' SOB DIFERENTES PERÍODOS DE EXPOSIÇÃO AO

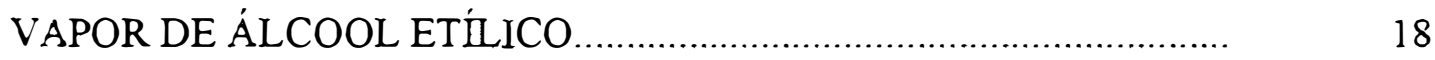

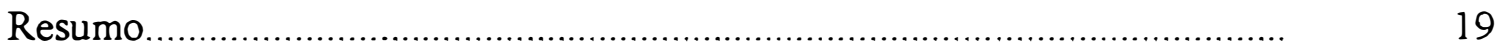

Abstract

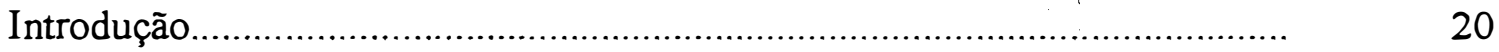

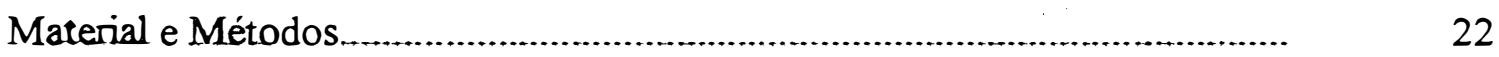

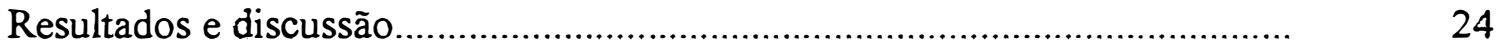

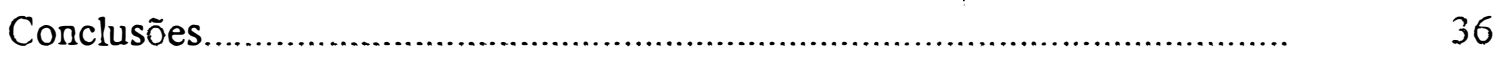

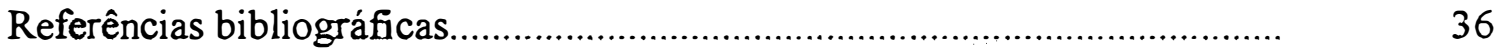


4 REMOÇÃO DA ADSTRINGÊNCIA E QUALIDADE DE FRUTOS DE CAQUIZEIRO 'GIOMBO' SUBMETIDOS À EMBALAGEM DE POLIETILENO E DIFERENTES PERÍODOS DE ARMAZENAMENTO REFRIGERADO .................................................. 40

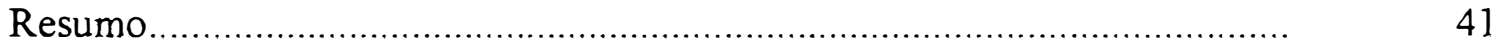

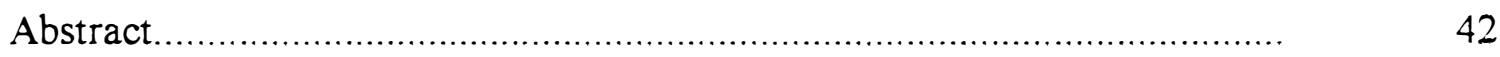

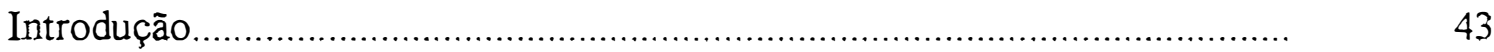

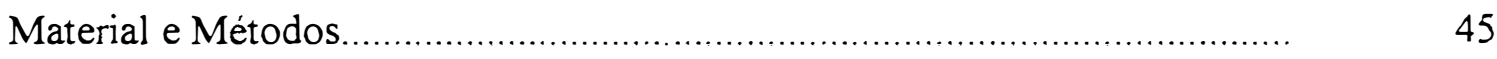

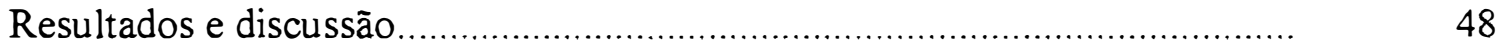

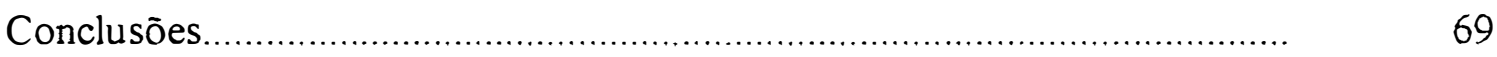

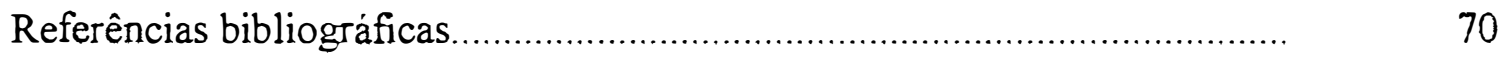

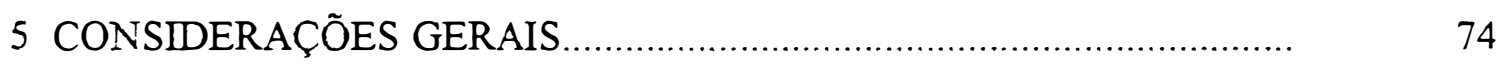

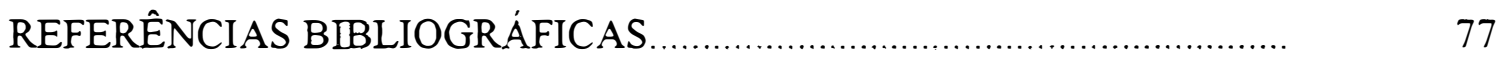




\section{LISTA DE FIGURAS}

Página

\section{Revisão de Literatura}

1 - Volume médio (1991-1997) de frutos de caquizeiro comercializado no CEAGESP - SP.

Remoção da adstringência de frutos de caquizeiro 'Giombo' sob diferentes períodos de exposição ao vapor de álcool etílico

1 - Teor de taninos solúveis de frutos de caquizeiro 'Giombo', durante o periodo de 10 dias subsequentes à exposição ao vapor de álcool etílico

2 - Firmeza da polpa de frutos de caquizeiro 'Giombo', durante o periodo de 10 dias subsequentes à exposição ao vapor de álcool etílico

3 - Perda de matéria fresca de frutos de caquizeiro 'Giombo' durante o período de exposição ao vapor de álcool etílico.

4 - Perda de matéria fresca de frutos de caquizeiro 'Giombo', durante o periodo de 10 dias subsequentes à exposição ao vapor de álcool etílico

5 - Potencial hidrogeniônico da polpa de frutos de caquizeiro 'Giombo', durante o período de 10 dias subsequentes à exposição ao vapor de álcool etílico.

6 - Teor de sólidos solúveis totais de frutos de caquizeiro 'Giombo', durante o período de 10 dias subsequentes à exposição ao vapor de álcool etílico.

7 - Acidez total titulável de frutos de caquizeiro 'Giombo', durante o período de 10 dias subsequentes à exposição ao vapor de álcool etílico 
8 - Teor de ácido ascórbico de frutos de caquizeiro 'Giombo', durante o período de 10 dias subsequentes à exposição ao vapor de álcool etílico

Remoção da adstringência e qualidade de frutos de caquizeiro 'Giombo' submetidos à embalagem de polietileno e diferentes períodos de armazenamento refrigerado

1 - Perda de matéria fresca de frutos de caquizeiro 'Giombo' durante o período de exposição ao vapor de álcool etílico (Após 30 dias de armazenamento refrigerado)

2 - Perda de matéria fresca de frutos de caquizeiro 'Giombo' durante o período de exposição ao vapor de álcool etílico (Após 60 dias de armazenamento refrigerado) 


\section{LISTA DE TABELAS}

Página

Remoção da adstringência de frutos de caquizeiro 'Giombo' sob diferentes períodos de exposição ao vapor de álcool etílico

1 - Análise de variância dos efeitos de diferentes periodos de exposição e do tempo de avaliação sobre as variáveis analisadas em frutos de caquizeiro 'Giombo'

Remoção da adstringência e qualidade de frutos de caquizeiro 'Giombo' submetidos à embalagem de polietileno e diferentes períodos de armazenamento refrigerado

1 - Análise de variância dos efeitos da utilização de embalagem e de diferentes periodos de armazenamento sobre as variáveis analisadas em frutos de caquizeiro 'Giombo'.

2 - Efeito da embalagem de polietileno e do periodo de armazenamento sobre as variáveis analisadas em frutos de caquizeiro 'Giombo' armazenados à temperatura de $1^{\circ} \mathrm{C}$

3 - Análise de variância dos efeitos da utilização de embalagem durante o armazenamento refrigerado e do período de avaliação sobre as variáveis analisadas em frutos de caquizeiro 'Giombo'.

4 - Efeito da embalagem de polietileno durante o armazenamento e do período de avaliação após a remoção da adstringência sobre as variáveis analisadas em frutos de caquizeiro 'Giombo' armazenados por 30 dias a $1^{\circ} \mathrm{C}$ e $95-98 \%$ UR. 
5 - Análise de variância dos efeitos da utilização de embalagem durante o armazenamento refrigerado e do período de avaliação sobre a perda de matéria fresca em frutos de caquizeiro 'Giombo'.....

6 - Efeito da embalagem de polietileno durante 60 dias de armazenamento refrigerado sobre as características fisicas e químicas de frutos de caquizeiro 'Giombo' no processo de remoção da adstringência

7 - Efeito da embalagem de polietileno durante o armazenamento e do periodo de avaliação após a remoção da adstringência sobre a perda de matéria fresca (\%) de frutos de caquizeiro 'Giombo' armazenados por 60 dias a $1{ }^{\circ} \mathrm{C}$ e $95-98 \%$ UR 


\section{LISTA DE ABREVIATURAS E SÍMBOLOS}

${ }^{\circ} \mathrm{C}$ - graus Celsius

AC - atmosfera controlada

ACC - ácido L-aminociclopropano carboxílico

AM - atmosfera modificada

B.O.D. - Biologic Oxygen Demand

CEAGESP - Companhia de Entrepostos e Armazéns Gerais de São Paulo

$\mathrm{CO}_{2}$ - dióxido de carbono

CT - coeficiente de transpiração

DCFI - 2,6-diclorobenzenoindofenol

DPV - déficit de pressão de vapor

INPM - Instituto Nacional de Pesos e Medidas

$\mathrm{mm}$ - milímetros

$\mathrm{N}$ - normal

$\mathrm{NaOH}$ - hidróxido de sódio

nm - nanômetros

$\mathrm{O}_{2}$ - oxigênio

PCA - polinização constante e adstringente

PCNA - polinização constante e não-adstringente

$\mathrm{pH}$ - potencial hidrogeniônico

PVA - polinização variável e adstringente

PVC - cloreto de polivinila

PVNA - polinização variável e não-adstringente

UR - umidade relativa 


\title{
REMOÇÃO DA ADSTRINGÊNCIA E ARMAZENAMENTO REFRIGERADO DE FRUTOS DE CAQUIZEIRO (Diospyros kaki L.) cv. GIOMBO
}

\author{
Autora: LUCLMARA ROGÉRIA ANTONIOLLI \\ Orientador: Prof. Dr. PAULO ROBERTO DE CAMARGO E CASTRO
}

\section{RESUMO}

Foram realizados dois experimentos nos quais se buscou avaliar a vida útil póscolheita de frutos de caquizeiro (Diospyros kaki L.) cultivar Giombo submetidos ao processo de remoção da adstringência, mediante a exposição ao vapor de álcool etílico. No primeiro experimento procurou-se estudar o efeito de diferentes períodos de exposição dos frutos ao vapor de etanol $\left(24,36\right.$ e 48 horas), sob temperatura de $20^{\circ} \mathrm{C}$ e 95\% UR. No segundo experimento procurou-se avaliar o efeito da utilização de embalagem de polietileno $(0,06 \mathrm{~mm})$ no acondicionamento dos frutos durante diferentes períodos de armazenamento refrigerado (30,60 e 90 dias), onde manteve-se temperatura de $1{ }^{\circ} \mathrm{C}$ e umidade relativa entre 95 e $98 \%$. Ao término de cada período de armazenamento os frutos foram expostos ao vapor de álcool etílico durante 40 horas, sob temperatura de $20^{\circ} \mathrm{C}$ e $95 \%$ UR. As variáveis analisadas, para ambos os experimentos, foram: teor de taninos solúveis, firmeza da polpa, perda de matéria fresca, $\mathrm{pH}$, sólidos solúveis totais, acidez total titulável e teor de ácido ascórbico.

De acordo com os resultados obtidos no primeiro experimento, os períodos de 24 e 36 horas demonstraram ser igualmente eficientes no processo de remoção da adstringência dos frutos; no entanto, a avaliação dos demais parâmetros indicou melhor qualidade dos frutos quando expostos durante o período de 24 horas. Constatou-se uma diminuição linear na firmeza da polpa em função do tempo. O melhor período para consumo dos frutos situou-se entre o $4^{\circ}$ e o $8^{\circ}$ dia após o tratamento, considerando-se que a partir do $4^{\circ}$ dia a concentração de taninos solúveis ficou abaixo de $0,1 \%$, 
imperceptível ao paladar, e a firmeza da polpa dos frutos se manteve aceitável durante o período de oito dias posteriores ao tratamento.

No segundo experimento verificou-se que os frutos mantiveram a qualidade durante os primeiros 30 dias de armazenamento, apresentando, aos 60 dias, redução na qualidade comercial decorrente da aparência pouco atrativa e da baixa firmeza de polpa. A utilização da embalagem de polietileno $(0,06 \mathrm{~mm})$ não apresentou eficiência na remoção total da adstringência dos frutos, havendo necessidade de um tratamento adicional para completar a destanização. Frutos armazenados por 30 dias e submetidos ao vapor de álcool etílico tomaram-se não adstringentes após três dias do tratamento, no entanto, a firmeza insuficiente da polpa associada à elevada perda de matéria fresca tornou os frutos pouco aceitáveis comercialmente. 


\title{
ASTRINGENCY REMOVAL AND COLD STORAGE OF PERSIMMON \\ FRUITS (Diospyros kaki L.) cv. GIONBO
}

\author{
Author: LUCIMARA ROGÉRIA ANTONIOLLI \\ Adviser: Prof. Dr. PAULO ROBERTO DE CAMARGO E CASTRO
}

\section{SUMMARY}

Two researches were carried out to evaluate the shelf life of persimmon fruits (Diospyros kaki L.) cultivar Gionbo submitted at astringency removal process through the exposure to ethanol vapor. The purpose of the first work was to study the effect of different exposure periods of fruits to ethanol vapor (24,36 and 48 hours), at $20^{\circ} \mathrm{C}$ and $95 \% \mathrm{RH}$. The second work was carried out to study the effect of the use of polyethylene bags $(0.06 \mathrm{~mm})$ in the packing of fruits during different periods of cold storage $(30,60$ and 90 days), at $1^{\circ} \mathrm{C}$ and $95-98 \%$ RH. Fruits were exposed to ethanol vapor for 40 hours at $20^{\circ} \mathrm{C}$ and $95 \% \mathrm{RH}$ at the end of each storage period. Soluble tannin content, flesh firmness, water loss, $\mathrm{pH}$, soluble solids, titratable acidity and ascorbic acid content were measured for both researches. The first experiment showed that the 24 and 36 hours were equally efficient in the astringency removal of fruits, although the analysis of other quality indices showed that fruits exposed for 24 hours exhibited better quality. The flesh firmness underwent a linear decrease in terms of time. The best period for consumption of the fruits was placed between the $4^{\underline{\underline{t h}}}$ and $8^{\underline{\underline{t h}}}$ day after the treatment. Fruits became edible at $4^{\text {th }}$ day after the treatment, when the content of soluble tannins was under $0.1 \%$, imperceptible to taste, and the flesh firmness was kept for 8 days after the treatment. The second experiment showed that fruits kept quality during the first 30 days of storage and showed decrease in the commercial quality after 60 days of cold storage, resulting from not enough attractive appearance and low firmness of the flesh. The use of polyethylene bags $(0.06 \mathrm{~mm})$ did not completely remove the astringency of the fruits, which were submitted at additional treatment for astringency removal. Fruits in storage for 30 days and submitted at ethanol vapor became non-astringents 3 days 
after the treatment, although the insufficient firmness of the flesh associated to high water loss resulted in fruits not enough acceptable commercially. 


\section{1 - INTRODUÇÃO}

A cultura do caquizeiro, introduzida no Brasil no final do século passado, revestiu-se de grande importância nas regiões Sudeste e Sul, onde encontrou condições favoráveis ao seu desenvolvimento. O Estado de São Paulo destaca-se atualmente como maior produtor, sendo responsável por aproximadamente $50 \%$ da produção nacional.

Dentre os cultivares recomendados para o cultivo comercial no Estado de São Paulo encontra-se o 'Giombo', fato justificado pela boa aceitação dos frutos, decorrente da aparência bastante atrativa e excelente sabor, associada à elevada produtividade e vigor das plantas.

O fato da produção estar concentrada num curto periodo de tempo, que para a maioria dos cultivares estende-se de fevereiro a maio, gera uma grande oferta do produto no mercado, o que invariavelmente conduz os preços a niveis bastante baixos. $\mathrm{O}$ desenvolvimento de tecnologia pós-colheita adequada à melhor conservação dos frutos reveste-se de grande importância, uma vez que proporcionaria uma dilatação no período de comercialização, de forma a oferecer o produto numa época do ano em que normalmente estaria pouco disponível, além de evitar a queda excessiva dos preços.

$\mathrm{O}$ armazenamento refrigerado destaca-se como uma possibilidade no prolongamento da vida pós-colheita dos frutos, no entanto, mesmo sob condições adequadas de temperatura e umidade relativa nas câmaras não se obtém conservação satisfatória dos frutos por períodos relativamente longos, em função da perda de matéria fresca, mudanças na firmeza e incidência de podridões. A utilização de embalagem de polietileno durante o armazenamento refrigerado surge como uma possibilidade na diminuição da perda de matéria fresca, uma vez que promove redução nas diferenças entre as pressões de vapor, além de proporcionar o desenvolvimento de atmosfera 
modificada que age de forma a retardar a senescência dos frutos. Particularmente na conservação do caqui, a embalagem de polietileno apresenta como efeito benéfico adicional a possibilidade de insolubilização dos taninos, com conseqüente redução na adstringência dos frutos.

A adstringência é uma característica marcante dos frutos imaturos de caquizeiro, no entanto, frutos de cultivares como o Giombo, preservam essa característica mesmo quando maduros, o que os torna pouco aceitáveis ao consumo in natura, necessitando, pois, de um processo artificial para a remoção da adstringência. A necessidade de se obter frutos destanizados num curto periodo de tempo associada à manutenção da firmeza da polpa durante a vida pós-colheita, tem conduzido à procura por agentes eficientes e práticos, capazes de promover a remoção da adstringência e manter as qualidades desejáveis dos frutos. $O$ álcool etilico vem sendo utilizado em maior proporção em relação aos demais agentes destanizadores, por possibilitar a obtenção de frutos com boa firmeza de polpa após o processo de destanização, característica importante para o cultivar Giombo, cujos frutos são consumidos com polpa firme.

A partir do conhecimento destes problemas, procurou-se, no presente trabalho, ampliar o periodo de conservação dos frutos de caquizeiro 'Giombo' utilizando-se para isto a refrigeração e a embalagem de polietileno, bem como adaptar o processo de remoção da adstringência, de forma a determinar o periodo de exposição ao vapor de álcool etílico que proporcione melhor qualidade dos frutos após o processo. 


\section{2 - REVISÃO DE LITERATURA}

\section{1 - Considerações gerais}

O caquizeiro (Diospyros kaki L.) é originário do continente asiático, mais precisamente da China (Salunkhe \& Desai, 1984; Ragazzini, 1985). Introduzido no Brasil no final do século passado, mostra grande potencial de expansão, dado a excelente adaptação às condições brasileiras (Penteado, 1986)

Os frutos de caquizeiro apresentam ótima aceitação no mercado, devido ao excelente sabor, boa aparência e elevada qualidade nutricional (Martins \& Pereira, 1989).

Simão (1998) relatou que a área ocupada pela cultura do caquizeiro no Brasil mantém-se em níveis estacionários, não ultrapassando 4.062 hectares. O Estado de São Paulo, maior produtor, é responsável por quase 50\% da produção nacional, com 2.217 hectares. De fato, o caquizeiro se destaca como uma das frutíferas de maior importância econômica entre as demais de características climáticas temperado-subtropicais no Estado de São Paulo. Com cerca de 700 mil plantas em cultivo comercial e uma produção estimada de 40 mil toneladas, apresenta como principais pólos produtores as regiões de Mogi das Cruzes, Jundiaí, Campinas e Atibaia, além de outras, no Sudoeste e Oeste paulista (Campo-Dall'Orto et al., 1996).

De acordo com dados obtidos no Anuário da Agricultura Brasileira (1999), o volume de caqui comercializado no CEAGESP de São Paulo, durante o ano de 1997, foi 
de 43.660 toneladas, volume este superior aos constatados nos anos anteriores, exceto no ano de 1994, quando o volume comercializado atingiu 48.087 toneladas.

A maturação dos frutos ocorre de fevereiro a maio, sendo que fora desse período há escassez do produto no mercado (Brackmann \& Saquet, 1995), decorrente do próprio ciclo da cultura e da carência de tecnologia adequada à conservação dos frutos.

Tal fato pode ser verificado na Figura 1, que indica a sazonalidade dos volumes comercializados no CEAGESP de São Paulo.

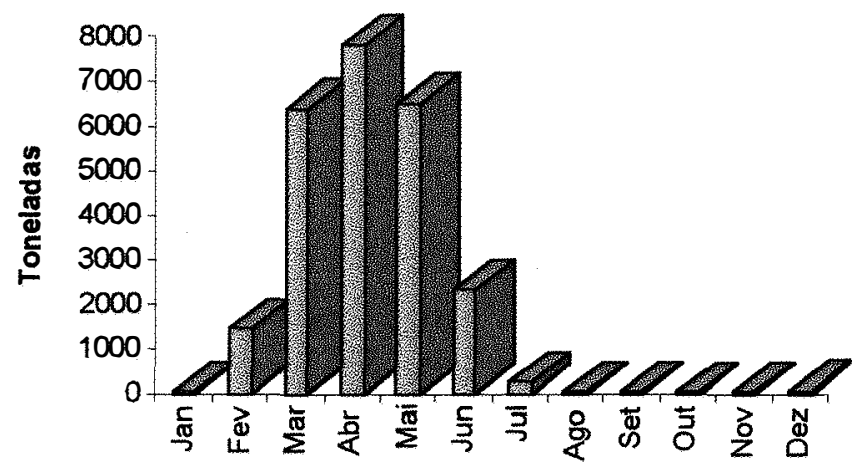

Figura 1 - Volume médio (1991-1997) de frutos de caquizeiro comercializado no CEAGESP - SP (Anuário da Agricultura Brasileira, 1999).

Os cultivares de caquizeiro japoneses podem ser divididos em dois tipos distintos, aqueles cujos frutos não apresentam mudança na coloração da polpa em função da polinização (constantes em relação à polinização - PC) e aqueles cujos frutos apresentam polpa clara quando partenocárpicos e escura quando fecundados (variáveis em relação à polinização - PV). Os frutos podem ser, ainda, subdivididos em cultivares adstringentes (A) e não-adstringentes (NA) (Ito, 1971). Dessa forma, os cultivares de caquizeiro podem ser classificados entre os tipos básicos: PCA, PCNA e PV, sendo que os frutos dos cultivares de polinização variável podem ser adstringentes ou nãoadstringentes.

Dependendo do teor de tanino e da presença ou não de coloração "chocolate" na polpa, próximo às sementes, os frutos são classificados, nas condições brasileiras, entre 
os três diferentes tipos básicos: taninoso ("shibugaki"), variável ("variant shibugaki" ou "variant amagaki") e doce ("amagaki"), conforme Campo-Dall'Orto et al. (1996).

Dentre os cultivares recomendados para o cultivo comercial no Estado de São Paulo, encontra-se o Giombo, classificado por Ito (1971), como pertencente ao tipo PCA. Por outro lado, Martins \& Pereira (1989) classificam este cultivar como pertencente ao tipo variável, apresentando polpa bastante taninosa quando partenocárpicos e do tipo "chocolate" e, portanto, sem adstringência quando com numerosas sementes. O cultivar apresenta alta produtividade sendo considerado de maturação tardia, com período de colheita iniciando-se no mês de março e estendendo-se até fins de maio (Martins \& Pereira, 1989), o que possibilita boa rentabilidade numa exploração comercial visando o mercado interno (Costa, 1984).

\section{2 - Maturação, amadurecimento e senescência}

A maturação, o amadurecimento e a senescência são estádios seqüenciais que ocorrem durante a vida de um fruto.

A maturação corresponde a um processo fisiológico irreversivel que estabelece o final do desenvolvimento dos frutos e o início da senescência. Algumas modificações que ocorrem durante esta fase são: maturação das sementes, alterações na coloração, mudanças nas taxas respiratória e de produção de etileno, modificações na permeabilidade dos tecidos e amolecimento, como conseqüência das mudanças na composição das substâncias pécticas, assim como alterações na composição dos carboidratos, ácidos orgânicos, proteínas, compostos fenólicos e pigmentos, produção de compostos voláteis e desenvolvimento de ceras sobre a casca (Wills et al., 1981; Chitarra \& Chitarra, 1990).

O amadurecimento, que pode ser considerado como o final da maturação, corresponde basicamente às mudanças nos fatores sensoriais que aumentam a aceitabilidade do fruto para o consumo (Chitarra \& Chitarra, 1990). 
A senescência corresponde à fase posterior à maturação, quando os processos bioquímicos de degradação superam os de síntese, conduzindo os tecidos à morte e determinando a perecibilidade do fruto (Chitarra \& Chitarra, 1990).

\section{3 - Respiração}

A respiração consiste no principal processo fisiológico dos frutos colhidos, que utilizam suas próprias reservas de substratos, acumulados durante o crescimento e a maturação, para se manterem vivos. No entanto, as atividades não são única e exclusivamente catabólicas, uma vez que alguns órgãos vegetais utilizam a energia liberada pela respiração para dar continuidade à síntese de pigmentos, enzimas e outros materiais de estrutura molecular elaborada (Chitarra \& Chitarra, 1990).

A respiração pode ser descrita como a quebra oxidativa de substâncias complexas presentes nas células, como amido, açúcares e ácidos orgânicos em moléculas mais simples, como dióxido de carbono e água, com produção de energia e outras moléculas que podem ser utilizadas pela célula para reações de síntese (Wills et al., 1981).

A taxa respiratória é um excelente indicador da atividade metabólica do tecido (Wills et al., 1981), determinando, juntamente com o tipo ou padrão respiratório, a longevidade dos frutos na pós-colheita. Em função do padrão respiratório, os frutos podem ser classificados em dois grandes grupos: os não climatéricos, que apresentam um declínio constante na taxa respiratória em função do tempo; e os climatéricos, que apresentam um aumento marcante na taxa respiratória ao final do período de maturação, denominado período climatérico ou climatério (Wills et al., 1981; Chitarra \& Chitarra, 1990).

Segundo Wills et al. (1981), o caqui é considerado um fruto climatérico; no entanto, Takata (1983) relatou que os frutos de caquizeiro 'Fuyu' podem apresentar um padrão que difere de ambos, climatérico e não-climatérico, considerando-se que os frutos colhidos tardiamente deixaram de apresentar picos marcantes na taxa respiratória 
e na produção de etileno, característicos dos frutos colhidos no início da safra. De forma semelhante, Turk (1993) verificou que frutos colhidos em dois estádios diferentes de maturidade apresentaram comportamento diferenciado durante $o$ período de armazenamento refrigerado a que foram submetidos, sendo que os frutos da primeira colheita apresentaram um modelo climatérico típico, enquanto os frutos colhidos mais tardiamente apresentaram produção irregular de $\mathrm{CO}_{2}$ durante o armazenamento.

\section{4 - Etileno}

O etileno é o composto orgânico mais simples e, aparentemente, o único gás que participa da regulação dos processos fisiológicos das plantas (Awad \& Castro, 1992). Considerado como sendo o hormônio natural do amadurecimento, o aumento na sua biossintese constitui o evento que marca a transição entre as fases de crescimento e senescência do fruto (Chitarra \& Chitarra, 1990).

O precursor chave no metabolismo do etileno é o aminoácido L-metionina, sendo que a sintese do etileno é limitada pelo suprimento do ácido L-aminociclopropano carboxilico (ACC), seu precursor imediato (Chitarra \& Chitarra, 1990).

A concentração de etileno aumenta de forma drástica no periodo climatérico, podendo este incremento anteceder ou não a elevação da taxa respiratória (Chitarra \& Chitarra, 1990). De acordo com Awad (1993) constata-se, em frutos de caquizeiro, que o início da produção de etileno antecede o aumento climatérico da respiração.

A taxa de produção de etileno pode ser influenciada pelo ambiente, através da ação da temperatura, dos gases $\mathrm{CO}_{2}$ e $\mathrm{O}_{2}$ e da luz; bem como pelas injúrias causadas por insetos, doenças, efeitos mecânicos e químicos, temperatura, déficit hídrico e radiação. Outro fator que pode modificar a produção de etileno corresponde aos reguladores vegetais, através das auxinas, giberelinas, citocininas, ácido abscísico e retardadores de crescimento (Felippe, 1986).

Os métodos de conservação de frutos climatéricos devem ter como objetivo a inibição ou a redução da síntese e dos efeitos do etileno, de forma a retardar o processo 
de amadurecimento; daí a importância do manejo dos frutos sob baixas temperaturas, bem como a utilização de atmosfera controlada ou modificada em pós-colheita (Felippe, 1986)

\section{5 - Transpiração}

O teor de água na maioria dos frutos varia entre 80 e $95 \%$, parte do qual é perdido pelo processo de transpiração (Chitarra \& Chitarra, 1990). A intensidade da perda de água na forma de vapor, através do processo transpiratório, tem importância substancial durante a comercialização dos frutos, uma vez que altas perdas de água resultam em murchamento e perda de consistência, refletindo em redução na qualidade dos frutos (Woods, 1990; Awad, 1993).

De acordo com Bender (1986), a transpiração é conseqüência do déficit de pressão de vapor (DPV) e do coeficiente de transpiração (CT). O DPV é a diferença entre a pressão de vapor dos espaços intercelulares do fruto e o ar circundante (Chitarra $\&$ Chitarra, 1990), enquanto que o CT consiste na perda de umidade pelo fruto em uma unidade de tempo por DPV (Woods, 1990). Quanto maior o déficit de pressão de vapor entre o fruto e o ar circundante maior será a perda de água pelo fruto (Chitarra \& Chitarra, 1990).

O déficit de pressão de vapor é dependente da temperatura e da umidade relativa do ar. Segundo Harvey et al. (1972), a perda de vapor de água, sob condições idênticas de umidade relativa do ar, é maior sob temperaturas mais elevadas; enquanto que para uma mesma temperatura, a perda de vapor de água é maior sob condições de umidade relativa mais baixa.

A utilização de filmes plásticos como PVC (cloreto de polivinila) e polietileno promove o desenvolvimento de um ambiente saturado, reduzindo o déficit de pressão de vapor entre o fruto e o interior da embalagem e evitando, dessa forma, a perda de vapor de água pelos frutos (Grierson \& Wardowski, 1978). 


\section{6 - Remoção da adstringência}

A adstringência constitui o maior problema à qualidade dos frutos de caquizeiro, sendo que frutos imaturos são acentuadamente adstringentes devido ao elevado teor de tanino solúvel em água, presente em células especializadas. $\mathrm{O}$ tanino coagulado ou polimerizado, por ser insolúvel em água, não apresenta adstringência (Taylor, 1993).

A redução na adstringência durante o crescimento e a maturação dos frutos de cultivares adstringentes e o desaparecimento da adstringência, naqueles não adstringentes, são refletidos no conteúdo de tanino do fruto. Kato (1984a) constatou alta correlação entre o grau de adstringência e a concentração de tanino, sendo que frutos contendo aproximadamente $0,25 \%$ de tanino mostraram-se ligeiramente adstringentes, enquanto aqueles contendo menos de $0,1 \%$ revelaram-se praticamente não adstringentes.

Frutos de caquizeiros do tipo PCA contêm aproximadamente $2 \%$ de taninos solúveis no momento da colheita. Tais frutos podem conter mais de $5 \%$ de taninos três semanas após a antese, quando então os taninos solúveis começam a diminuir, atingindo o valor de $2 \%$ na colheita. Após a colheita, o teor de taninos solúveis ainda diminui e os frutos tomam-se comestiveis quando seu teor encontra-se abaixo de 0,1\% (Vidrih et al., 1994). Ao mesmo tempo em que a concentração de taninos solúveis diminui, a concentração de acetaldeído e etanol aumenta dez vezes após a colheita (Sugiura et al., 1979).

Segundo constatações de Sugiura et al. (1979), possivelmente haja o envolvimento de dois diferentes mecanismos na perda natural da adstringência; sendo que um deles é dependente da produção de etanol e, presumivelmente, acetaldeído pelas sementes durante o desenvolvimento dos frutos, estando associado aos tipos PVNA, PVA e PCA; enquanto supõe-se que o segundo mecanismo, constatado em frutos de cultivares do tipo PCNA, esteja mais relacionado ao menor tamanho das células de tanino, de baixo peso molecular e menor reatividade, do que ao grau de coagulação (Taylor, 1993). Sugiura et al. (1979) verificaram que os frutos de cultivares 
adstringentes acumulam baixos níveis de etanol e acetaldeido durante todo o periodo de crescimento e desenvolvimento.

Uma vez que são, na sua maioria, consumidos in natura, os frutos dos cultivares adstringentes requerem remoção artificial da adstringência antes do consumo. São vários os produtos que podem ser utilizados para a remoção da adstringência do caqui, como álcool, vinagre, água de cal, etileno e carbureto de cálcio (Penteado, 1986). Tais tratamentos estimulam o acúmulo de compostos voláteis na polpa dos frutos, como etanol e acetaldeído, e estas substâncias, especialmente o acetaldeído, induzem os taninos solúveis a se polimerizarem e formarem complexos insolúveis, resultando na perda da adstringência (Sugiura \& Tomana, 1983; Vidrih et al., 1994). Taninos altamente condensados são menos solúveis e apresentam menor capacidade de se ligar a outros componentes celulares (Van Buren, 1970).

Costa (1984), avaliando o comportamento de alguns cultivares de caquizeiro, afirmou que os frutos de 'Giombo' destacaram-se entre os melhores para o consumo in natura, após serem submetidos, durante um periodo de 60 horas, ao tratamento com acetileno, proveniente de carbureto de cálcio à proporção de 100 g.m ${ }^{-3}$, realizado em câmara de amadurecimento.

De acordo com constatações de Pesis et al. (1986), o acondicionamento dos frutos em embalagem de polietileno consiste num método alternativo que propicia o desenvolvimento de um ambiente com alta concentração de dióxido de carbono. Vidrih et al. (1994) citaram que frutos de caquizeiro mantidos sob atmosfera com alta concentração de $\mathrm{CO}_{2}$ acumulam elevadas concentrações de etanol e acetaldeído, como resultado das modificações no processo respiratório. $\mathrm{O}$ acetaldeído formado durante o tratamento pode reagir com os taninos solúveis causando sua polimerização e tornandoos insolúveis (Ito, 1971).

A remoção da adstringência dos frutos decorrente do tratamento com água aquecida não é devida à ocorrência de mudanças químicas, como polimerização ou condensação, mas sim à geleificação do protoplasma das células de tanino (Ito, 1971). 
Manabe $^{1}$ (1982) citado por Taylor (1993), constatou que o tratamento com etanol resultou em frutos contendo aproximadamente 13 vezes mais substâncias insolúveis que os frutos não tratados, o que toma o etanol um agente destanizador com grande potencial.

Kato (1987), avaliando o amadurecimento e a perda de adstringência de frutos de caquizeiro 'Aizumishirazu' e 'Hiratanenashi' durante o tratamento com etanol na faixa de temperatura de 5 a $40^{\circ} \mathrm{C}$, constatou que o teor de tanino diminuiu mais rapidamente sob temperaturas elevadas. A qualidade dos frutos se manteve por um periodo igual ou superior a 10 dias quando os frutos foram tratados à temperatura de 15 ou $20^{\circ} \mathrm{C}$.

Frutos de caquizeiro 'Okira' colhidos no final de abril, cerca de 196 dias após a floração, foram submetidos aos seguintes processos de destanização: aplicação de $1 \mathrm{ml}$ de vinagre no cálice dos frutos ou imersão total dos frutos em solução de álcool a 50\% ou em solução de ethephon a $300 \mathrm{mg} . \mathrm{L}^{-1}$. A concentração de tanino nos frutos submetidos aos diferentes processos de destanização foi eliminada próximo ao sexto dia após a colheita, enquanto que os frutos controle ainda apresentavam cerca de $0,8 \%$ de tanino (Biasi \& Gerhardt, 1992). Estes autores relataram que os frutos tratados com álcool apresentaram, após o processo de destanização, resistência de polpa de 1,1 $\mathrm{kg} . \mathrm{cm}^{-2}$, superior àquela encontrada nos frutos tratados com vinagre e ethephon. Este resultado confirmou as observações de Martins \& Pereira (1989) que citaram o álcool como um agente destanizador que possibilitava a obtenção de frutos com polpa firme após o processo.

Biasi \& Gerhardt (1992) também observaram uma redução significativa no valor do $\mathrm{pH}$ da polpa à medida que os frutos tomaram-se maduros. Constataram, em todos os tratamentos, um aumento na acidez titulável até o quarto dia após a colheita, seguido por uma redução, tendo a acidez atingido valores praticamente semelhantes ao do momento da colheita. De acordo com estes autores, as causas desta oscilação são

\footnotetext{
${ }^{1}$ MANABE, T. Changes of insoluble nitrogen compounds during the process of removing astringency in the Japanese persimmon cultivar Saijyo: Journal of the Japanese Society for Food Science Technology, v.29, p.677-679, 1982.
} 
desconhecidas, no entanto sua ocorrência foi concomitante à alteração da consistência da polpa dos frutos, que se tornou cada vez mais gelatinosa.

A remoção da adstringência de frutos de caquizeiro 'Hiratanenashi', através do tratamento com álcool seguida pelo armazenamento dos frutos à temperatura de 2 ou $20^{\circ} \mathrm{C}$, resultou em um lento declínio na firmeza dos frutos mantidos sob baixa temperatura, sendo que o teor de ácido ascórbico foi ligeiramente alterado em ambos os tratamentos (Taira et al., 1987).

Itamura et al. (1991) constataram que a polpa de frutos de caquizeiro 'Hiratanenashi' começou a se tornar amolecida após 48 horas do tratamento com etanol, sendo que tanto o amolecimento da polpa quanto a evolução do etileno tornaram-se mais rápidos quanto maiores as concentrações utilizadas. Frutos tratados com etanol apresentaram um aumento na sintese de etileno cerca de 24 horas após o tratamento (Kato, 1984b; Itamura et al., 1991)

O etileno é considerado um ativador do mecanismo de amolecimento de frutos de caquizeiro (Itamura et al., 1991). Conforme constatações de Itamura et al. (1997), o tratamento com vapor de álcool, bem como outros tratamentos para a remoção da adstringência, acelera a síntese de etileno e, portanto, o amolecimento do fruto.

Fukushima et al. (1991) verificaram que frutos de caquizeiro 'Hiratanenashi' perderam sua adstringência mais rapidamente quando expostos, em recipiente fechado, à solução de etanol a $35 \%$, quando comparados àqueles tratados com solução de acetaldeido a $5 \%$.

Taira et al. (1991) obtiveram caquis destanizados 6 dias após o tratamento, quando acondicionaram frutos maduros em recipientes de 1 litro contendo $5 \mathrm{~cm}^{3}$ de solução de etanol a $10 \%$, periodo este reduzido para 4-6 dias quando utilizaram solução de etanol à concentração de $30 \%$.

Para remoção da adstringência de frutos de caquizeiro 'Yokono' (PCA), 'Hagakushi' (PCA), 'Kuramitsu' (PCA) e 'Monpei' (PVA), Taira et al. (1992) acondicionaram os frutos, individualmente, em câmaras com volume de $900 \mathrm{ml}$, 
mantidas à temperatura de $20^{\circ} \mathrm{C}$ e contendo solução de etanol a 10 ou $30 \%$. A razão e a quantidade de frutos que sofreram amolecimento durante o tratamento com etanol variou dependendo do cultivar. Frutos de 'Kuramitsu' tratados com etanol a $30 \%$ e frutos dos demais cultivares tratados com etanol a 10\% permaneceram ainda adstringentes após 6 dias do tratamento. Os autores sugeriram que o tanino polimeriza-se imediatamente naqueles cultivares que acumulam acetaldeído rapidamente em níveis elevados e que a concentração de taninos solúveis diminui lentamente em função da penetração do etanol através da epiderme dos frutos e/ou devido ao metabolismo do álcool a acetaldeído.

Frutos de caquizeiro 'Aizumishirazu' e 'Hiratanenashi' tratados com solução de etanol a $50 \%$ durante 1 dia, a $20^{\circ} \mathrm{C}$, apresentaram uma rápida diminuição no teor de tanino, constatando-se, no entanto, uma "fase lag" de aproximadamente dois dias antes que tivesse início a diminuição no teor de tanino (Kato, 1984b). De forma semelhante, Fukushima et al. (1991) verificaram que o tratamento com etanol promoveu uma leve perda da adstringência durante os dois primeiros dias subsequentes ao tratamento, que se acentuou nos 2 dias seguintes.

Taira et al. (1990) verificaram que frutos de caquizeiro mais imaturos apresentaram maior rapidez na diminuição do teor de taninos solúveis quando submetidos ao tratamento com solução de etanol a 30\% em câmaras plásticas mantidas a $20^{\circ} \mathrm{C}$. Constatou-se que houve um maior acúmulo de acetaldeído na polpa dos frutos jovens, quando comparados aos frutos maduros. Estes resultados estão de acordo com as observações de Taylor (1993), que relatou que a remoção da adstringência ocorre mais rapidamente em frutos jovens quando comparada aos frutos mais maduros, possivelmente em função de uma conversão mais ativa do etanol a acetaldeído.

O problema de qualidade verificado nos frutos de caquizeiro dos cultivares adstringentes é igualmente constatado em frutos de bananeira 'Amas', que tendem a conservar sua adstringência mesmo quando maduros, o que afeta sua aceitabilidade. $\mathrm{O}$ tratamento com etanol as concentrações de 25 a $75 \%$ realizado isoladamente ou em conjunto com etileno a $1000 \mathrm{mg} . \mathrm{L}^{-1}$, no estádio pré-climatérico, reduziu rapidamente o conteúdo total de compostos fenólicos quando comparado ao controle ou aos frutos 
tratados somente com etileno. Não se constataram efeitos fitotóxicos mesmo com a utilização das concentrações mais elevadas de etanol (Esguerra et al., 1992).

\section{7 - Armazenamento refrigerado e utilização de embalagem}

O armazenamento refrigerado destaca-se como uma possibilidade no prolongamento da vida pós-colheita dos frutos, refletindo na dilatação do período de comercialização. A conservação dos frutos é dependente do ponto de maturação, do cultivar e das condições de temperatura e umidade relativa das câmaras (Martins \& Pereira, 1989). De acordo com Lyon et al. (1992), os caquis se conservam melhor à temperatura de $1^{\circ} \mathrm{C}$.

Ito (1971) afirma que as condições ótimas para o armazenamento do caqui conjugam $8 \%$ de $\mathrm{CO}_{2}, 3-5 \%$ de $\mathrm{O}_{2}, 90-100 \%$ de umidade relativa e temperatura de $1{ }^{\circ} \mathrm{C}$. $\mathrm{O}$ armazenamento em atmosfera controlada (AC) apresenta o efeito desejável de atrasar o amarelecimento do cálice, resultando em frutos de boa qualidade e em condições comerciais após 3 meses de armazenamento.

Os frutos podem ser embalados em sacos de polietileno com espessura de 0,06 mm e armazenados a $0^{\circ} \mathrm{C}$, o que promove uma ligeira modificação nas condições do armazenamento em $\mathrm{AC}$, isto é, a combinação de $5 \% \mathrm{CO}_{2} \operatorname{com} 5-8 \% \mathrm{O}_{2}$ e quase $100 \%$ de umidade relativa (Ito, 1971).

A utilização de embalagens de polietileno, visando a conservação dos frutos, promove uma modificação na atmosfera ao redor destes, devido à respiração do produto, que eleva a concentração de $\mathrm{CO}_{2}$ e diminui a concentração de $\mathrm{O}_{2}$ (Pesis et al., 1986). Com o aumento do $\mathrm{CO}_{2}$ ocorre uma redução na síntese e na ação do etileno, hormônio responsável pelo amadurecimento nos futos climatéricos, como o caqui (Chitarra \& Chitarra, 1990). Em alguns casos, a atmosfera modificada que se desenvolve no interior da embalagem pode ser benéfica, uma vez que retarda a senescência; por outro lado, a elevada concentração de $\mathrm{CO}_{2}$ em adição ao acúmulo de etanol podem provocar danos aos frutos (Pesis et al., 1986). 
Ben-Arie \& Zutkhi (1992) conseguiram prolongar a vida pós-colheita de caqui 'Fuyu' de 6 para 18 semanas, a $0^{\circ} \mathrm{C}$, com a utilização de filme de polietileno de baixa densidade. $\mathrm{O}$ uso da atmosfera modificada (AM) inibiu o desenvolvimento de desordens na casca e na polpa, que limitaram a vida pós-colheita dos frutos não embalados. Quando transferidos à temperatura de $20^{\circ} \mathrm{C}$, os frutos embalados em sacos de polietileno com espessura de $0,08 \mathrm{~mm}$ mantiveram suas qualidades internas e externas durante o período de uma semana, sendo que os frutos embalados em sacos de $0,06 \mathrm{~mm}$ perderam sua qualidade mais rapidamente. A diferença entre a qualidade dos frutos nas duas embalagens foi atribuida aos efeitos fisiológicos especificos decorrentes dos dois diferentes equilibrios atmosféricos estabelecidos pela espessura dos filmes utilizados.

Kawada $^{2}$ (1982) citado por Pekmezci et al. (1997), mostrou que frutos de caquizeiro 'Fuyu', no Japão, puderam ser armazenados durante 5 a 6 meses, a $0^{\circ} \mathrm{C}$, quando acondicionados, individualmente, em sacos de polietileno com espessura de 0,06 $\mathrm{mm}$. Neste experimento, o amolecimento dos frutos foi um importante fator limitante durante o armazenamento. Frutos do mesmo cultivar, na Nova Zelândia, puderam ser armazenados satisfatoriamente por somente 4 semanas, sob as mesmas condições, sendo o fator limitante, a injúria pelo frio, não necessariamente acompanhada por amolecimento dos frutos (Ben-Arie \& Zutkhi, 1992; Pekmezci et al., 1997).

Lee \& Yang (1997) constataram menor ocorrência de desordens fisiológicas e melhor qualidade de frutos de caquizeiro 'Fuyu' quando estes eram acondicionados em filme de polietileno de $0,05 \mathrm{~mm}$ durante 90 dias de armazenamento.

Frutos de caquizeiro embalados à vácuo, acondicionados individualmente em sacos de polietileno $(0,08 \mathrm{~mm})$ e armazenados à temperatura de $1^{\circ} \mathrm{C}$, apresentaram um alto grau de firmeza durante 10 semanas de armazenamento. Ao final do período a firmeza dos frutos variou de 7,0 a $11,0 \mathrm{~kg} . \mathrm{cm}^{-2}$, sendo que o teor de taninos solúveis ficou abaixo de $0,03 \%$ (Li et al., 1998).

\footnotetext{
${ }^{2} \mathrm{KAWADA}, \mathrm{K}$. Use of polymeric films to extend postharvest life and improve marketability of fruits and vegetables-Unipeck: Individually wrapped storage of tomatoes, oriental persimmons and grapefruit. Symposium Series, Oregon State University, School of Agriculture, n. 1, p.87-99, 1982.
} 
Hong et al. (1993) mostraram que frutos de caquizeiro 'Cheongdo-Bansi' e 'Sangju-Dungsi', cultivares de frutos adstringentes, embalados em sacos de polietileno com espessura de $0,08 \mathrm{~mm}$ e armazenados sob temperaturas entre 0 e $3^{\circ} \mathrm{C}$, apresentaram menor amolecimento, não havendo, entretanto, alteração no teor de sólidos solúveis totais. Após 44 dias de armazenamento, os frutos de 'Cheongdo-Bansi', mantidos em sacos de $0,08 \mathrm{~mm}$, estavam suficientemente doces para serem comercializados. A concentração de $\mathrm{CO}_{2}$ no interior dos sacos de polietileno $(0,05 \mathrm{~mm}$ e $0,08 \mathrm{~mm})$ para ambos os cultivares foi mais elevada após 7 dias de armazenamento refrigerado e então permaneceu constante ao nível de 5-6\%. Não se constatou o desenvolvimento de desordens fisiológicas durante os 64 dias de armazenamento.

Awad \& Amenomori (1971) relataram que o confinamento de frutos de caquizeiro 'Taubaté' em sacos de polietileno não apresentou efeito algum sobre a destanização dos frutos, possivelmente devido a pouca espessura da embalagem, o que resultou em uma permeabilidade muito alta e em baixo acúmulo de $\mathrm{CO}_{2}$, necessário para induzir à destanização.

Frutos de caquizeiro 'Fuyu' provenientes da região de Bursa, Turquia, foram colhidos com máximo crescimento e coloração laranja avermelhada em duas épocas distintas de maturação. Os frutos foram embalados em sacos de polietileno com espessura de $0,03 \mathrm{~mm}$, sendo que os frutos da primeira colheita foram armazenados por 80 dias e os da segunda por 70 dias à temperatura de $1{ }^{\circ} \mathrm{C}$ e $90 \%$ de umidade relativa. A concentração de sólidos solúveis totais diminuiu continuamente durante $\mathrm{O}$ armazenamento. Os açúcares totais, bem como os açúcares invertidos diminuíram durante o armazenamento, no entanto, a diminuição no teor de açúcares invertidos cessou após 50 dias de armazenamento, aumentando em seguida. Isto indica que houve uma perda da adstringência dos frutos, que se tomaram apropriados ao consumo (Turk, 1993).

No entanto, Moura et al. (1997) avaliando frutos de caquizeiro 'Taubaté', embalados ou não com película de PVC e armazenados à temperatura de $0^{\circ} \mathrm{C}$, verificaram que o teor de sólidos solúveis foi crescente com o tempo e maior nos frutos 
sem embalagem. De acordo com estes autores, a principal causa do aumento no teor de sólidos solúveis foi a perda de água por transpiração durante o armazenamento, que foi mais evidente nos frutos sem embalagem. Quanto à acidez titulável, a utilização de embalagem não causou efeito significativo durante o período de armazenamento a $0^{\circ} \mathrm{C}$.

Turk (1993) constatou uma diminuição no teor de vitamina C durante o armazenamento dos frutos de caquizeiro, bem como na firmeza de todos os frutos, sendo que aqueles da primeira colheita perderam sua qualidade de comercialização após 40-60 dias do início do periodo de armazenamento. Este autor afirmou que os frutos de caquizeiro 'Fuyu' podem ser armazenados por um período de 2 a 3 meses, quando colhidos na época de maturação ideal e armazenados sob condições de $90 \%$ de umidade relativa e temperatura de $0^{\circ} \mathrm{C}$.

Moura et al. (1997) constataram que a temperatura de $0^{\circ} \mathrm{C}$ foi eficiente em retardar o amadurecimento dos frutos de caquizeiro 'Taubaté', principalmente quando embalados com película de PVC. Ao final do armazenamento, os frutos embalados apresentaram-se com maior teor de clorofila total e menor teor de sólidos solúveis que aqueles não embalados. Os autores verificaram que a perda de massa foi crescente durante o periodo de armazenamento nos frutos não embalados e reduzida nos frutos embalados. De acordo com Pesis et al. (1986), esta redução é decorrente da alta umidade relativa no interior da embalagem, que reduz o déficit de pressão de vapor e, consequentemente, a transpiração dos frutos.

Segundo Moura et al. (1997), a utilização de embalagem não interferiu na firmeza da polpa, constatando-se uma diminuição linear em função do tempo. A redução na firmeza é regulada principalmente por dois processos enzimáticos: a ação da pectinametilesterase e da poligalacturonase (Kader, 1985).

Moura et al. (1997) relataram que a utilização de embalagem durante o periodo de 72 dias de armazenamento não foi suficiente para reduzir o teor de tanino e o grau de adstringência dos frutos de caquizeiro 'Taubaté', havendo necessidade de indução ao amadurecimento para que ocorresse maturação homogênea dos frutos. 


\section{3 - PRIMEIRO TRABALHO CIENTÍFICO}

REMOÇÃO DA ADSTRINGÊNCIA DE FRUTOS DE CAQUIZEIRO 'GIOMBO' SOB DIFERENTES PERÍODOS DE EXPOSIÇÃO AO VAPOR DE ÁLCOOL ETÍLICO

LUCIMARA ROGÉRIA ANTONIOLLI² E PAULO ROBERTO DE CAMARGO E CASTRO $^{3}$

\footnotetext{
${ }^{1}$ Parte da Dissertação de Mestrado em Fisiologia e Bioquímica de Plantas do primeiro autor.

${ }^{2}$ Pós-graduanda em Fisiologia e Bioquímica de Plantas. ESALQ - USP, Piracicaba (SP).

${ }^{3}$ Prof. Titular do Deparamento de Ciências Biológicas. ESALQ - USP, Piracicaba (SP).
} 


\title{
REMOÇÃO DA ADSTRINGÊNCIA DE FRUTOS DE CAQUIZEIRO 'GIOMBO' SOB DIFERENTES PERÍODOS DE EXPOSIÇÃO AO VAPOR DE ÁLCOOL ETÍLICO
}

\section{RESUMO}

Neste trabalho, procurou-se estudar o efeito do periodo de exposição de frutos de caquizeiro (Diospyros kaki L.) cultivar Giombo ao vapor de álcool etilico. Os frutos foram expostos ao vapor de etanol durante diferentes períodos ( 24,36 ou 48 horas), a $20^{\circ} \mathrm{C}$ e $95 \%$ UR. As características químicas e fisicas dos frutos foram avaliadas durante 10 dias, em intervalos de 2 dias. As variáveis analisadas foram: teor de taninos solúveis, firmeza da polpa, perda de matéria fresca, $\mathrm{pH}$, sólidos solúveis totais, acidez total titulável e teor de ácido ascórbico. De acordo com os resultados obtidos, os períodos de 24 e 36 horas demonstraram ser igualmente eficientes no processo de remoção da adstringência dos frutos; no entanto, a avaliação dos demais parâmetros indicou melhor qualidade dos frutos expostos durante o periodo de 24 horas. Constatou-se uma diminuição linear na firmeza da polpa em função do tempo. O melhor período para consumo dos frutos situou-se entre o $4^{\circ}$ e o $8^{\circ}$ dia após o tratamento, considerando-se que a partir do $4^{\circ}$ dia a concentração de taninos solúveis ficou abaixo de 0,1\%, imperceptível ao paladar, e a firmeza da polpa dos frutos se manteve aceitável durante o período de oito dias posteriores ao tratamento.

Palavras-chave: Diospyros kaki, tanino, etanol.

\author{
ASTRINGENCY REMOVAL OF 'GIONBO' PERSIMMON FRUIT IN \\ DIFFERENT EXPOSURE PERIODS TO ETHANOL VAPOR
}




\begin{abstract}
The purpose of this research was to study the effect of exposure period of persimmon fruits (Diospyros kaki L.) cultivar Gionbo to ethanol vapor. Fruits were exposed to ethanol vapor for different periods $\left(24,36\right.$ or 48 hours) at $20^{\circ} \mathrm{C}$ and $95 \% \mathrm{RH}$. Chemical and physical characteristics of fruits were measured for 10 days, at 2 days intervals. Soluble tannin content, flesh firmness, water loss, $\mathrm{pH}$, soluble solids, titratable acidity and ascorbic acid content were measured. This research showed that 24 and 36 hours were equally efficient in the astringency removal of fruits, although the analysis of other quality indices showed that fruits exposed for 24 hours exhibited better quality. The flesh firmness underwent a linear decrease in terms of time. The best period for consumption of the fruits was placed between the $4^{\underline{\underline{t h}}}$ and $8^{\underline{\underline{t h}}}$ day after the treatment. Fruits became edible at $4^{\text {th }}$ day after the treatment, when the content of soluble tannins was under $0.1 \%$, imperceptible to taste, and the flesh firmness was kept for 8 days after the treatment.
\end{abstract}

Key words: Diospyros kaki, tannin, ethanol.

\title{
INTRODUÇÃO
}

Os cultivares de caquizeiro (Diospyros kaki L.) de origem japonesa podem ser divididos em dois tipos distintos, aqueles cujos frutos não apresentam mudança na coloração da polpa em função da polinização (constantes em relação à polinização - PC) e aqueles cujos frutos apresentam polpa clara quando partenocárpicos e escura quando fecundados (variáveis em relação à polinização - PV). Os frutos podem ser, ainda, subdivididos em cultivares adstringentes (A) e não-adstringentes (NA) (Ito, 1971). Dessa forma, os cultivares de caquizeiro podem ser classificados entre os tipos básicos: PCA, PCNA e PV, sendo que os frutos dos cultivares de polinização variável podem ser adstringentes ou não-adstringentes. 
Dependendo do teor de tanino e da presença ou não de coloração "chocolate" na polpa, próximo às sementes, os frutos são classificados, nas condições brasileiras, entre os três diferentes tipos básicos: taninoso ("shibugaki"), variável ("variant shibugaki" ou "variant amagaki") e doce ("amagaki"), conforme Campo-Dall'Orto et al. (1996).

O cultivar Giombo é classificado por Ito (1971), como pertencente ao tipo PCA, no entanto, Martins \& Pereira (1989) citam o cultivar como pertencente ao tipo variável, apresentando frutos com polpa bastante taninosa quando partenocárpicos e do tipo "chocolate" e, portanto, sem adstringência quando com numerosas sementes. Nos frutos com poucas sementes, a coloração escura é verificada somente ao redor delas (Martins \& Pereira, 1989).

Uma vez que são, na sua maioria, consumidos in natura, os frutos dos cultivares adstringentes requerem remoção artificial da adstringência anterior ao consumo. São vários os produtos que podem ser utilizados na remoção da adstringência do caqui, como álcool, vinagre, água de cal, etileno, ethephon e carbureto de cálcio (Penteado, 1986; Biasi \& Gerhardt, 1992). Tais tratamentos estimulam o acúmulo de compostos voláteis na polpa dos frutos, como etanol e acetaldeído, e estas substâncias, especialmente o acetaldeído, induzem os taninos solúveis a se polimerizarem e formarem complexos insolúveis, resultando, com isso, na perda da adstringência (Sugiura \& Tomana, 1983). Taninos altamente condensados são menos solúveis e apresentam menor capacidade de se ligar a outros componentes celulares (Van Buren, 1970).

Costa (1984), avaliando o comportamento de alguns cultivares de caquizeiro, afirmou que os frutos do 'Giombo' destacaram-se entre os melhores para o consumo in natura, após serem submetidos, durante um período de 60 horas, ao tratamento com acetileno, proveniente de carbureto de cálcio à proporção de $100 \mathrm{~g} \cdot \mathrm{m}^{-3}$, realizado em câmara de amadurecimento.

Os frutos de caquizeiro 'Okira' tratados com álcool apresentaram, após o processo de destanização, resistência de polpa superior aos frutos tratados com vinagre e ethephon (Biasi \& Gerhardt, 1992). Este resultado confirmou as observações de Martins 
\& Pereira (1989), que citaram o álcool como um agente destanizador que possibilitou a obtenção de frutos com polpa firme após o processo. Pesis et al. (1986) associaram o início do amolecimento da polpa de frutos de caquizeiro 'Triumph' ao valor de firmeza de $4,2 \mathrm{~kg} \cdot \mathrm{cm}^{-2}$.

Conforme observações de Fukushima et al. (1991), o tratamento com etanol proporcionou maior rapidez no processo de perda da adstringência em caquis 'Hiratanenashi' quando comparado ao tratamento com acetaldeído. Quando realizado sob temperaturas de 15 ou $20^{\circ} \mathrm{C}$, tal tratamento possibilitou a manutenção da qualidade dos frutos por um periodo igual ou superior a 10 dias (Kato, 1987).

O objetivo deste trabalho foi avaliar a remoção da adstringência de frutos de caquizeiro, cultivar Giombo, submetidos a diferentes periodos de exposição ao vapor de álcool etílico, avaliando-se as alterações fisico-químicas dos frutos após o processo de destanização e a manutenção da qualidade para consumo.

\section{MATERIAL E MÉTODOS}

Os frutos de caquizeiro 'Giombo' foram colhidos no início do mês de junho de 1998, em pomar comercial localizado no municipio de Guapiara, São Paulo, situado a $24^{\circ} 11^{\prime}$ de latitude Sul e $48^{\circ} 02^{\prime}$ de longitude Oeste e a 900 metros de altitude, com clima do tipo $\mathrm{Cfb}$, segundo Köppen.

Em função da colheita tardia, considerando-se que o periodo de colheita, para este cultivar, inicia-se no mês de março e estende-se até fins de maio (Martins \& Pereira, 1989), os frutos apresentavam coloração $100 \%$ alaranjada e bastante uniforme.

Os frutos foram transportados ao Laboratório de Fisiologia Pós-Colheita do Departamento de Ciências Biológicas da Escola Superior de Agricultura "Luiz de Queiroz", onde se realizou rigorosa seleção, visando a padronização dos frutos quanto ao tamanho, bem como a eliminação dos frutos com qualidade inferior à desejada. 
Foram selecionados 225 frutos e imediatamente acondicionados em bandejas de isopor ( $144 \times 208 \mathrm{~mm}$ ), totalizando 45 bandejas, contendo 5 frutos cada uma.

Os frutos foram então submetidos ao processo de remoção da adstringência mediante a exposição ao vapor de álcool etílico hidratado 92,8 INPM (álcool comercial). Para tal foram utilizadas câmaras B.O.D. (Biologic Oxygen Demand, Modelo TE 390-Tecnal) contendo 3,85 ml de álcool / L câmara $\left(3,85 \mathrm{~L} \cdot \mathrm{m}^{-3}\right)$. Durante o processo, a temperatura foi mantida a $20^{\circ} \mathrm{C}$ e a umidade relativa em torno de $95 \%$. Os frutos permaneceram expostos ao vapor de álcool etílico durante períodos distintos de 24,36 ou 48 horas.

Terminado o período de exposição, os frutos foram retirados das câmaras e colocados em bancadas de laboratório, à temperatura ambiente $\left(24-25^{\circ} \mathrm{C}\right)$.

As características químicas e fisicas dos frutos foram avaliadas em intervalos de dois dias, durante o periodo de 10 dias.

As variáveis analisadas foram: a) teor de taninos solúveis $\left(\mathrm{g} .100 \mathrm{~g}^{-1}\right.$ polpa): determinado espectrofotometricamente utilizando-se o reagente de Follin-Denis, segundo técnica recomendada por Carvalho et al. (1990), onde uma amostra de $5 \mathrm{~g}$ de polpa triturada e homogeneizada foi diluída para um volume final de $100 \mathrm{ml}$ com água destilada do qual se retirou uma aliquota de $5 \mathrm{ml}$. A esta alíquota se adicionou reagente de Follin-Denis e solução de carbonato de sódio, completando o volume a $100 \mathrm{ml} c \mathrm{~m}$ água destilada. Após um periodo de 30 minutos, a solução foi filtrada e em seguida determinou-se a absorbância a $760 \mathrm{~nm}$. Foi utilizada, como padrão, uma solução de ácido tânico $\left(0,1 \mathrm{~g} . \mathrm{L}^{-1}\right)$; b) firmeza de polpa $\left(\mathrm{kg} . \mathrm{cm}^{-2}\right)$ : medida com penetrômetro EFFEGI, com ponteira de 6,5 mm de diâmetro, efetuando-se duas leituras em lados opostos na região equatorial dos frutos, após a remoção de uma pequena área da casca. Associou-se o início do amolecimento da polpa ao valor de firmeza de $5 \mathrm{~kg} . \mathrm{cm}^{-2}$; c) perda de matéria fresca (\%): avaliada durante o período de exposição ao vapor de álcool etílico e calculada pela diferença, em porcentagem, entre a massa inicial e aquela obtida imediatamente após o tratamento. Avaliada durante os 10 dias após o tratamento, em intervalos de 2 dias, considerando-se como massa inicial aquela verificada 
imediatamente após o tratamento; d) $\mathrm{pH}$ : medido por potenciometria em amostra triturada e homogeneizada; e) sólidos solúveis totais ( $\left.{ }^{\circ} \mathrm{Brix}\right)$ : determinado por refratometria, com correção de temperatura para $20^{\circ} \mathrm{C}$; f) acidez total titulável (\% ácido málico): determinada através da diluição de $10 \mathrm{ml}$ da amostra em $90 \mathrm{ml}$ de água destilada, e posterior titulação com solução de $\mathrm{NaOH}$ a $0,1 \mathrm{~N}$, até $\circ \mathrm{pH}$ de 8,10; g) teor de ácido ascórbico (mg ácido ascórbico. $100 \mathrm{~g}^{-1}$ polpa): determinado segundo metodologia de Carvalho et al. (1990), a qual se baseia na redução do indicador 2,6diclorobenzenoindofenol (DCFI) pelo ácido ascórbico.

O delineamento experimental adotado foi inteiramente casualizado, no esquema fatorial $3 \times 5$, sendo 3 períodos de exposição ao vapor de álcool etílico: 24, 36 e 48 horas, e 5 tempos de avaliação: $2,4,6,8$ e 10 dias, perfazendo 15 tratamentos. A cada avaliação foram utilizadas 3 repetições com 5 frutos por parcela.

Os dados foram submetidos à análise de variância e as médias referentes à perda de matéria fresca durante o tratamento foram comparadas pelo teste de Tukey ao nivel de $5 \%$ de probabilidade. Realizou-se regressão polinomial para as médias referentes às demais variáveis, obtidas durante o período de 10 dias de avaliação.

Uma amostra representativa dos frutos foi submetida à uma avaliação prévia ao tratamento, objetivando a caracterização inicial dos mesmos.

\section{RESULTADOS E DISCUSSĀO}

Na Tabela 1 encontra-se resumida a análise da variância dos efeitos dos tratamentos sobre as diversas variáveis analisadas no experimento.

Observa-se que não houve efeito do período de exposição ao vapor de álcool etílico sobre a maioria das variáveis, o mesmo ocorrendo para a interação entre período de exposição e tempo de avaliação. Verifica-se, no entanto, que ambos os fatores, bem 
como a interação entre eles apresentaram efeito sobre as variáveis: taninos solúveis e firmeza de polpa.

Tabela 1 - Análise de variância dos efeitos de diferentes períodos de exposição e do tempo de avaliação sobre as variáveis analisadas em frutos de caquizeiro 'Giombo'. ESALQ, Piracicaba-SP, 1999.

\begin{tabular}{|c|c|c|c|c|c|c|c|c|}
\hline \multirow[b]{2}{*}{$\begin{array}{c}\text { Efeitos principais } \\
\text { e interação }\end{array}$} & \multicolumn{8}{|c|}{ Variáveis analisadas ${ }^{x}$} \\
\hline & TS & FP & $\mathrm{PMF}^{1}$ & $\mathrm{PMF}^{2}$ & $\mathrm{pH}$ & SST & ATT & $\mathrm{AA}$ \\
\hline & ------ & ------ & -----Sig & nificânci & a do te & te F--- & ----- & -----. \\
\hline Período de exposição (PE) & $*$ & $* *$ & $* *$ & n.s. & n.s. & n.s. & n.s. & n.s. \\
\hline Tempo de avaliação (TA) & $* *$ & $* *$ & - & $* *$ & $* *$ & n.s. & n.s. & $* *$ \\
\hline $\mathrm{PE} \times \mathrm{TA}$ & $* *$ & $*$ & - & n.s. & n.s. & n.s. & n.s. & n.s. \\
\hline C.V. $(\%)$ & 22,15 & 15,72 & 17,33 & 10,92 & 1,10 & 2,50 & 12,26 & 11,32 \\
\hline
\end{tabular}

${ }^{x} \mathrm{TS}=$ taninos solúveis: $\mathrm{FP}=$ firmeza de polpa; $\mathrm{PMF}^{\prime}=$ perda de matéria fresca durante o tratamento; $\mathrm{PMF}^{2}$ = perda de matéria fresca durante o período de avaliação; $\mathrm{pH}=$ potencial hidrogeniônico; SST = sólidos solúveis totais; $\mathrm{ATT}=$ acidez total titulável; $\mathrm{AA}=$ ácido ascórbico.

n.s.: **; * = não significativo; significativo ao nivel de 1 e $5 \%$ de probabilidade, respectivamente.

\section{Taninos solúveis}

Através da análise de regressão, pôde-se observar que houve uma diminuição no teor de taninos solúveis dos frutos durante o tempo de avaliação, linear para os submetidos aos tratamentos de 36 e 48 horas, e quadrática para os frutos submetidos ao período de 24 horas de exposição ao vapor de álcool etílico (Figura 1).

Observou-se, dois dias após o tratamento, que os frutos expostos ao período de 24 horas apresentaram o maior teor de taninos solúveis, equivalente a $0,20 \mathrm{~g} .100 \mathrm{~g}^{-1}$, 
ainda próximo ao teor de $0,28 \mathrm{~g} \cdot 100 \mathrm{~g}^{-1}$ verificado num periodo imediatamente anterior ao tratamento. Nos demais tempos de avaliação, os teores de taninos solúveis foram próximos para os diferentes periodos de exposição.

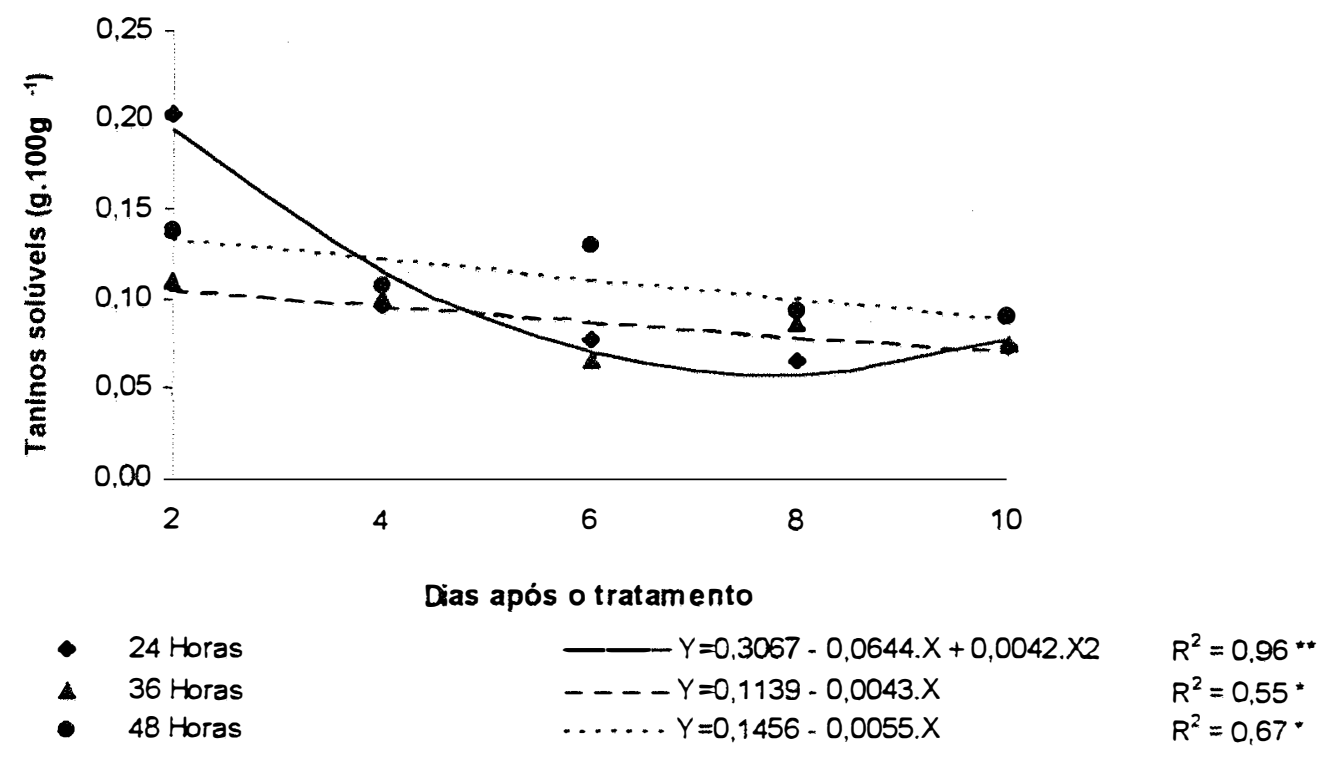

Figura 1 - Teor de taninos solúveis de frutos de caquizeiro 'Giombo', durante o período de 10 dias subsequentes à exposição ao vapor de álcool etílico. (Análise inicial = 0,28 g.100 $\mathrm{g}^{-1}$ ). ESALQ, Piracicaba-SP, 1999.

De acordo com constatações de Kato (1984a), frutos contendo aproximadamente $0,25 \%$ de tanino revelam-se ligeiramente adstringentes, tornando-se comestíveis quando a concentração de taninos solúveis encontra-se abaixo de $0,1 \%$ (Vidrih et al., 1994). No presente trabalho verificou-se que a partir do quarto dia do tratamento os teores de taninos solúveis foram bastante próximos a $0,1 \%$ em todos os tratamentos, indicando haver uma perda da adstringência dos frutos, o que foi confirmado através de avaliações degustativas.

Os resultados obtidos estão de acordo com os observados por Fukushima et al. (1991), que relataram a ocorrência de uma leve perda da adstringência durante os dois primeiros dias subsequentes ao tratamento dos frutos com solução de etanol a $35 \%$, que 
se acentuou nos dois dias seguintes. Kato (1984b), de forma semelhante, verificou a ocorrência de uma "fase lag" de aproximadamente dois dias, à temperatura de $20^{\circ} \mathrm{C}$, antes que tivesse início a diminuição do teor de tanino dos frutos tratados com etanol a $50 \%$

Biasi \& Gerhardt (1992) obtiveram frutos destanizados próximo ao sexto dia após o tratamento, quando os submeteram à imersão em solução de álcool a 50\%, durante dois minutos. Taira et al. (1992), ao verificarem a existência de frutos adstringentes após 6 dias do tratamento com etanol, sugeriram que o teor de taninos solúveis diminui lentamente em função da penetração do etanol através da epiderme do fruto e/ou devido ao metabolismo do álcool a acetaldeído.

\section{Firmeza da polpa}

Pôde-se observar, através da análise de regressão, que houve uma diminuição linear na firmeza da polpa em todos os tratamentos em função do tempo de avaliação (Figura 2).

Ao final do período de 10 dias, os frutos submetidos a 24 horas de exposição ao vapor de álcool etílico apresentaram firmeza de polpa de $5,56 \mathrm{~kg} . \mathrm{cm}^{-2}$, enquanto que os submetidos ao periodo de 48 horas apresentaram firmeza de $4,49 \mathrm{~kg} . \mathrm{cm}^{-2}$. Os frutos mais amolecidos, submetidos ao tratamento de 36 horas, apresentaram firmeza de polpa de $3,90 \mathrm{~kg} . \mathrm{cm}^{-2}$. Sugere-se que o melhor periodo para consumo dos frutos se estenda até o $8^{\circ}$ dia após o tratamento, quando verificou-se que a firmeza da polpa ainda se manteve aceitável para todos os tratamentos, considerando-se que os frutos deste cultivar são consumidos com polpa firme. 


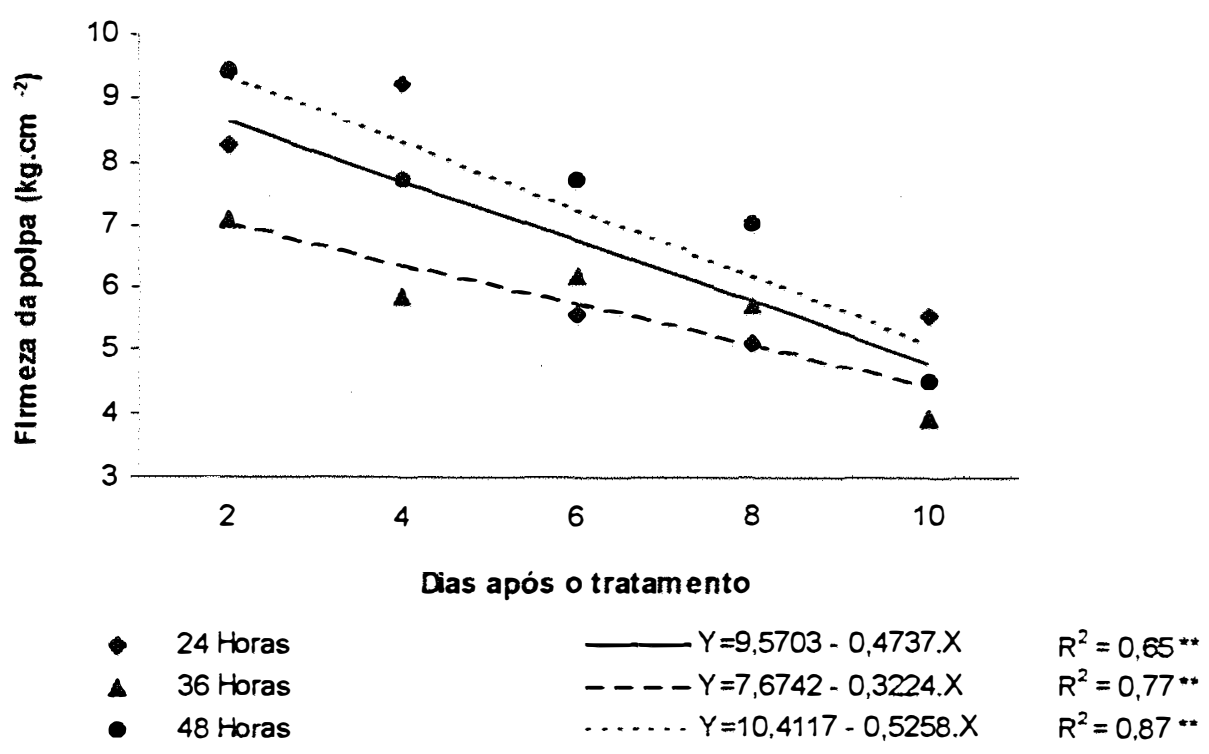

Figura 2 - Firmeza da polpa de frutos de caquizeiro 'Giombo', durante o período de 10 dias subsequentes à exposição ao vapor de álcool etílico. (Análise inicial = 10,53 kg.cm ${ }^{-2}$ ). ESALQ, Piracicaba-SP, 1999.

O etileno é considerado um ativador do mecanismo de amolecimento de frutos de caquizeiro (Itamura et al., 1991). Conforme constatações de Itamura et al. (1997), o tratamento com vapor de álcool, bem como outros tratamentos para a remoção da adstringência, acelera a síntese de etileno e, portanto, o amolecimento do fruto.

Frutos tratados com etanol apresentaram um aumento na síntese de etileno cerca de 24 horas após o tratamento (Kato, 1984b; Itamura et al., 1991), enquanto que o início do amolecimento da polpa dos frutos ocorreu somente após um período de 48 horas do tratamento (Itamura et al., 1991).

De forma semelhante às observações de Itamura et al. (1991), verificou-se, no presente experimento, uma diminuição na firmeza da polpa dos frutos dois dias após o 
término do tratamento, passando de $10,53 \mathrm{~kg} \cdot \mathrm{cm}^{-2}$ para $8,24,7,07$ e $9,41 \mathrm{~kg} \cdot \mathrm{cm}^{-2}$, para os períodos de 24,36 e 48 horas de exposição, respectivamente.

Tian et al. (1991) relataram uma diminuição na atividade da pectinaesterase concomitante à diminuição linear da firmeza da polpa de frutos de caquizeiro durante o período de armazenamento; verificaram, no entanto, um aumento no conteúdo de pectinas solúveis, bem como na atividade da celulase e da poligalacturonase. $\mathrm{O}$ aumento na atividade destas enzimas é responsável pela redução na força de coesão que mantém as células unidas, resultando na diminuição da firmeza da polpa (Moura, 1995).

\section{Perda de matéria fresca durante o tratamento}

Conforme pode ser observado na Figura 3, os frutos submetidos ao tratamento de 48 horas apresentaram maior perda de matéria fresca durante o período de exposição ao vapor de álcool etílico, seguidos pelos frutos submetidos aos tratamentos de 36 e 24 horas.

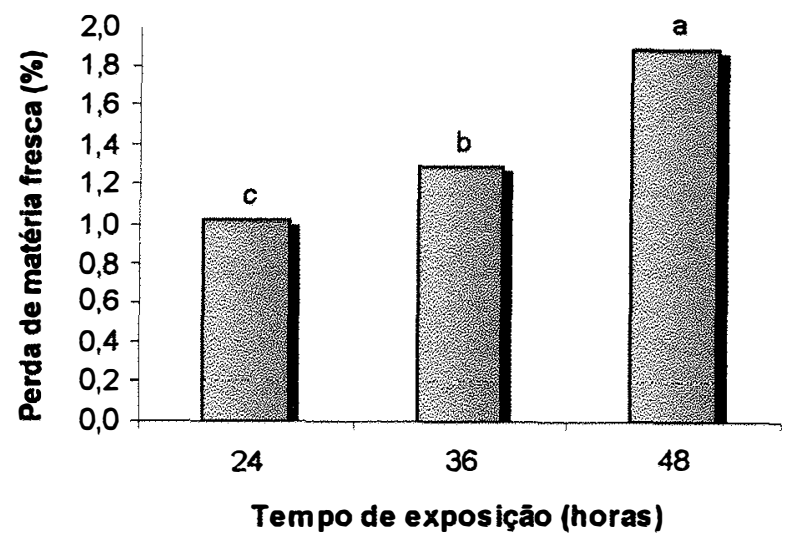

Figura 3 - Perda de matéria fresca de frutos de caquizeiro 'Giombo' durante o período de exposição ao vapor de álcool etílico. (As letras minúsculas indicam diferença significativa ao nível de $5 \%$ de probabilidade, pelo teste de Tukey). ESALQ, Piracicaba-SP, 1999. 


\section{Perda de matéria fresca durante o período de avaliação}

Através da análise de regressão, pôde-se observar que houve um aumento linear na perda de matéria fresca em função do tempo de avaliação (Figura 4), não havendo efeito do periodo de exposição sobre esta variável (Tabela 1).

Constatou-se, ao final do periodo de 10 dias, uma perda de matéria fresca equivalente a $5,34 \%$ da massa inicial obtida ao final do tratamento.

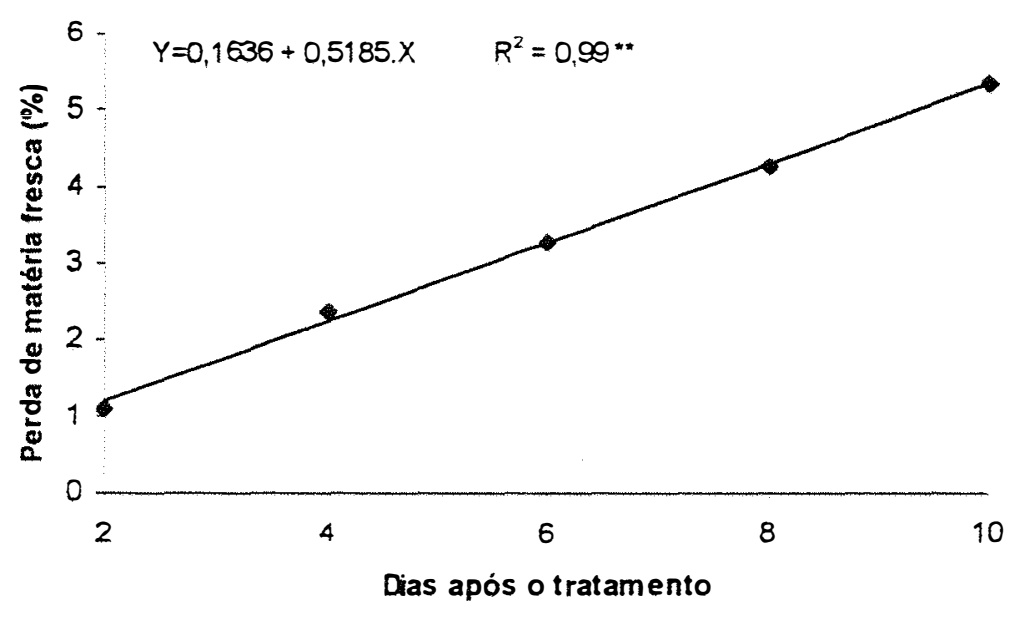

Figura 4 - Perda de matéria fresca de frutos de caquizeiro 'Giombo', durante o período de 10 dias subsequentes à exposição ao vapor de álcool etílico. ESALQ, Piracicaba-SP, 1999.

A perda de matéria fresca dos frutos ocorre principalmente devido ao processo de transpiração, em conseqüência do déficit de pressão de vapor (DPV) que corresponde à diferença entre a pressão de vapor dos espaços intercelulares do fruto e do ar circundante, e do coeficiente de transpiração (CT) do fruto que corresponde à perda de umidade de um produto em uma unidade de tempo por DPV (Woods, 1990).

Considerando-se que as perdas de matéria fresca entre 3 e $6 \%$ são suficientes para causar redução na qualidade de muitos produtos vegetais (Chitarra \& Chitarra, 
1990), sugere-se que os frutos submetidos a este processo de destanização sejam comercializados tão logo estejam aptos ao consumo, ou seja, a partir do $4^{\circ}$ dia após o tratamento, considerando-se, o teor de taninos solúveis e a perda de matéria fresca.

\section{Potencial hidrogeniônico (pH)}

Através da análise de regressão, constatou-se que a variação desta característica em função do tempo pôde ser representada através de uma equação quadrática (Figura $5)$.

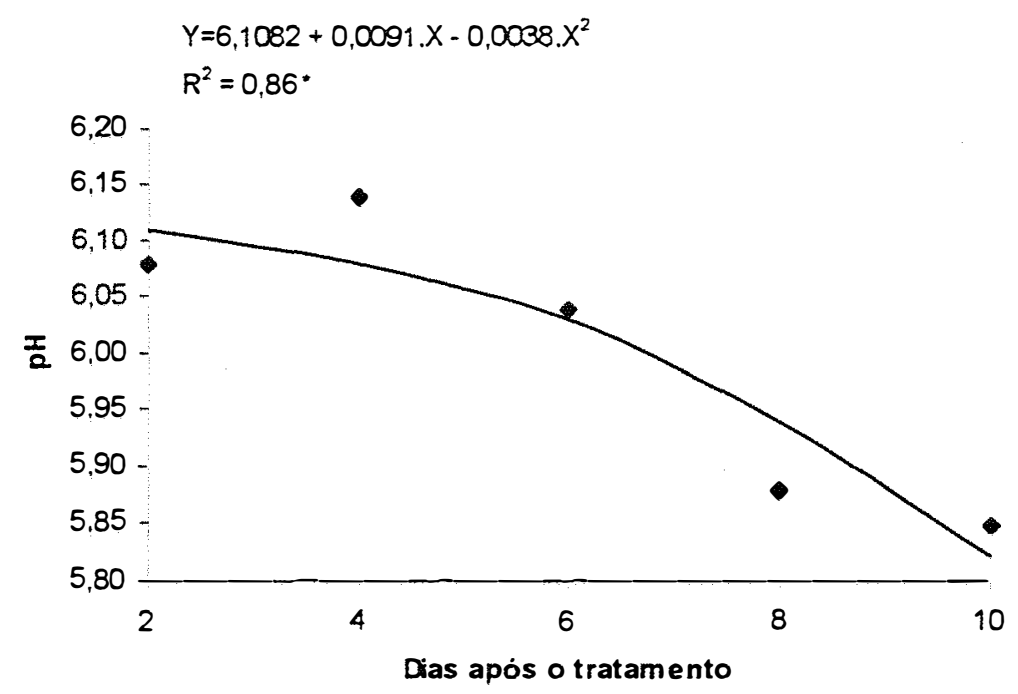

Figura 5 - Potencial hidrogeniônico da polpa de frutos de caquizeiro 'Giombo', durante o período de 10 dias subsequentes à exposição ao vapor de álcool etílico. (Análise inicial =6,22). ESALQ, Piracicaba-SP, 1999.

Verificou-se uma redução no valor do $\mathrm{pH}$ aos 2 dias após o tratamento, passando de 6,22, no período anterior ao tratamento, para 6,08. Os valores se mantiveram próximos até o sexto dia, verificando-se, a partir deste ponto, uma redução no valor de $\mathrm{pH}$, atingindo o valor de 5,85 ao final de 10 dias, valor este superior ao de 5,50 encontrado por Costa (1984), para frutos do mesmo cultivar submetidos ao tratamento com acetileno. 
Estes resultados estão de acordo com os obtidos por Biasi \& Gerhardt (1992), que verificaram uma redução significativa no $\mathrm{pH}$ com o amadurecimento dos frutos, durante o periodo de oito dias subsequentes ao tratamento com álcool. Moura (1995) obteve resultados semelhantes ao submeter caquis 'Taubaté' à pulverização com solução de ethephon a $1000 \mathrm{mg} . \mathrm{L}^{-1}$, visando induzi-los ao amadurecimento.

\section{Sólidos solúveis totais}

Observou-se, durante todo o periodo de avaliação, que os teores de sólidos solúveis mantiveram-se muitos próximos, apresentando-se, no entanto, superiores à média verificada durante a caracterização inicial dos frutos, equivalente a $20,87^{\circ} \mathrm{Brix}$ (Figura 6).

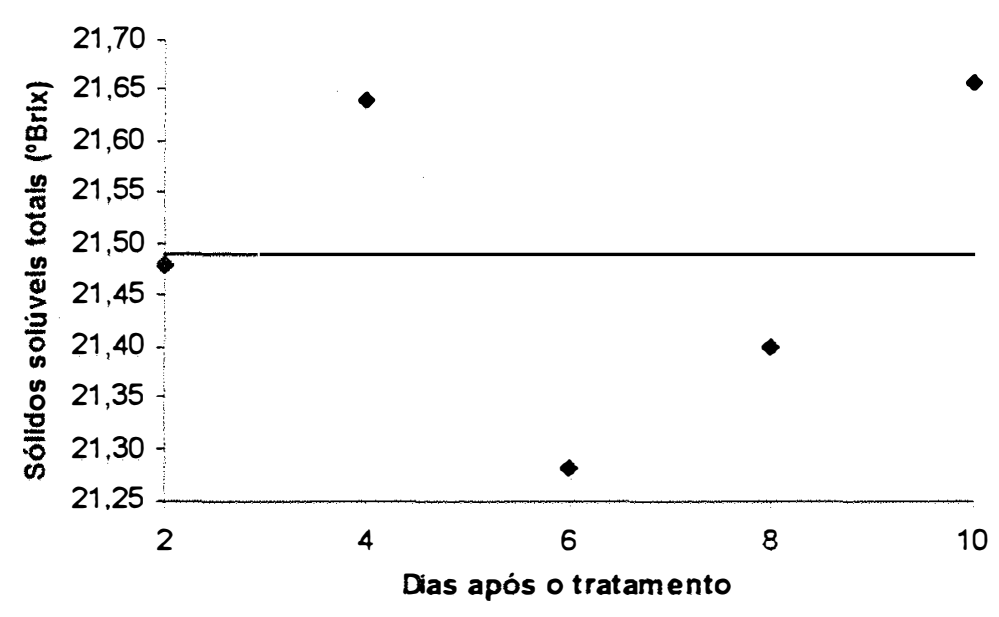

Figura 6 - Teor de sólidos solúveis totais de frutos de caquizeiro 'Giombo', durante o período de 10 dias subsequentes à exposição ao vapor de álcool etílico. (Análise inicial $=20,87^{\circ}$ Brix). ESALQ, Piracicaba-SP, 1999.

O aumento no teor de sólidos solúveis verificado em relação ao valor médio inicial, pode ser resultado da perda de matéria fresca pelos frutos durante o período de exposição ao vapor de álcool e da hidrólise de compostos, como substâncias pécticas e 
hemicelulose da parede celular, em conseqüência do avanço do amadurecimento, conforme sugerem Wills et al. (1981).

A ausência de aumento neste parâmetro, ao longo do periodo de avaliação, possivelmente esteja relacionada à respiração do fruto, que utilizou os açúcares como substrato para o processo. A perda de matéria fresca verificada nos frutos, que normalmente faz com que o teor de sólidos solúveis totais se eleve, provavelmente contrabalançou as perdas dos carboidratos utilizados no processo respiratório, havendo, portanto, pouca variação do parâmetro avaliado

\section{Acidez total titulável}

Era de se esperar que houvesse aumento na acidez, confirmando o comportamento do $\mathrm{pH}$, no entanto, constatou-se que os valores mantiveram-se muito próximos durante o periodo de 10 dias, não diferindo, inclusive, do valor médio de $0,0625 \%$ de ácido málico, verificado durante o periodo imediatamente anterior ao tratamento (Figura 7).

Embora não havendo diferença significativa entre os teores de acidez total titulável nos diferentes tempos de avaliação, verificou-se, ao segundo dia do tratamento, o menor valor médio de acidez, equivalente a $0,0655 \%$ de ácido málico. 


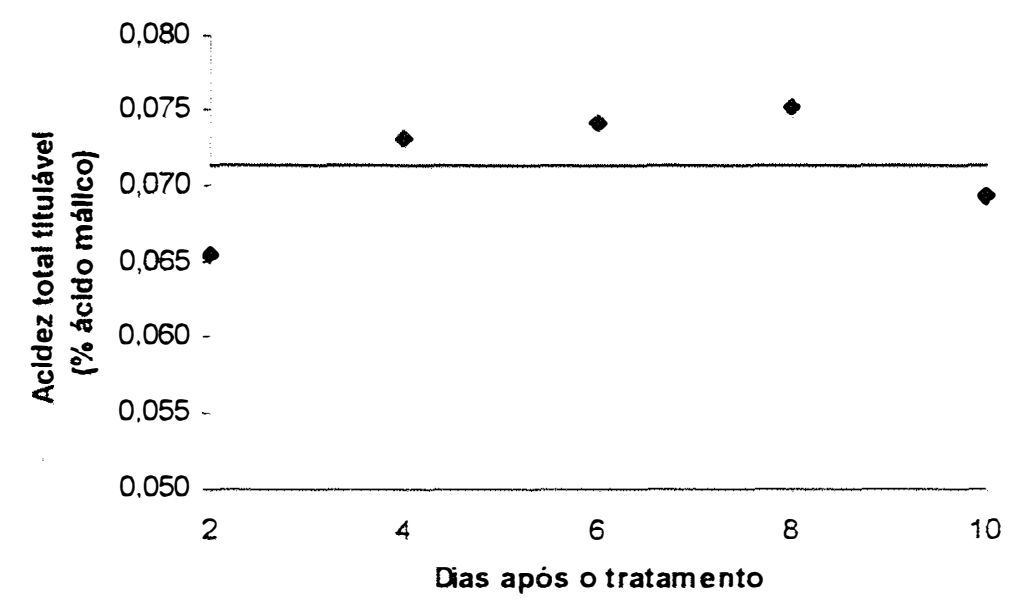

Figura 7 - Acidez total titulável de frutos de caquizeiro 'Giombo', durante o período de 10 dias subsequentes à exposição ao vapor de álcool etílico. (Análise inicial = 0,0625\% ácido málico). ESALQ, Piracicaba-SP, 1999.

O teor de ácidos orgânicos, com poucas exceções, diminui com a maturação, em decorrência do processo respiratório ou de sua conversão em açúcares (Chitarra \& Chitarra, 1990). No entanto, Moura (1995) atribuiu o aumento na acidez verificado em frutos de caquizeiro 'Taubaté' submetidos ao tratamento com ethephon, à intensa atividade metabólica, que conduz às transformações fisicas e químicas nos frutos. $O$ ácido poligalacturônico, proveniente da hidrólise da pectina pela pectinametilesterase e poligalacturonase (Wills et al., 1981), além da produção de intermediários do ciclo de Krebs, como os ácidos orgânicos alfa-ceto glutárico, cítrico e málico, pode contribuir para o aumento da acidez titulável (Moura, 1995).

\section{Ácido ascórbico}

Através da análise de regressão, constatou-se que a variação desta característica em função do tempo pôde ser representada através de uma equação linear (Figura 8). 
Observou-se um decréscimo linear no teor de ácido ascórbico a partir do segundo dia após o tratamento, atingindo o menor teor ao final do periodo, equivalente a $38,45 \mathrm{mg}$ de ácido ascórbico/ $100 \mathrm{~g}$ de polpa. Considerando-se que o teor médio de ácido ascórbico obtido imediatamente anterior ao tratamento foi de $61,39 \mathrm{mg} \cdot 100 \mathrm{~g}^{-1}$, constatou-se que houve uma perda de vitamina $C$ equivalente a $37,4 \%$, desde o início do tratamento até o término do periodo de avaliação.

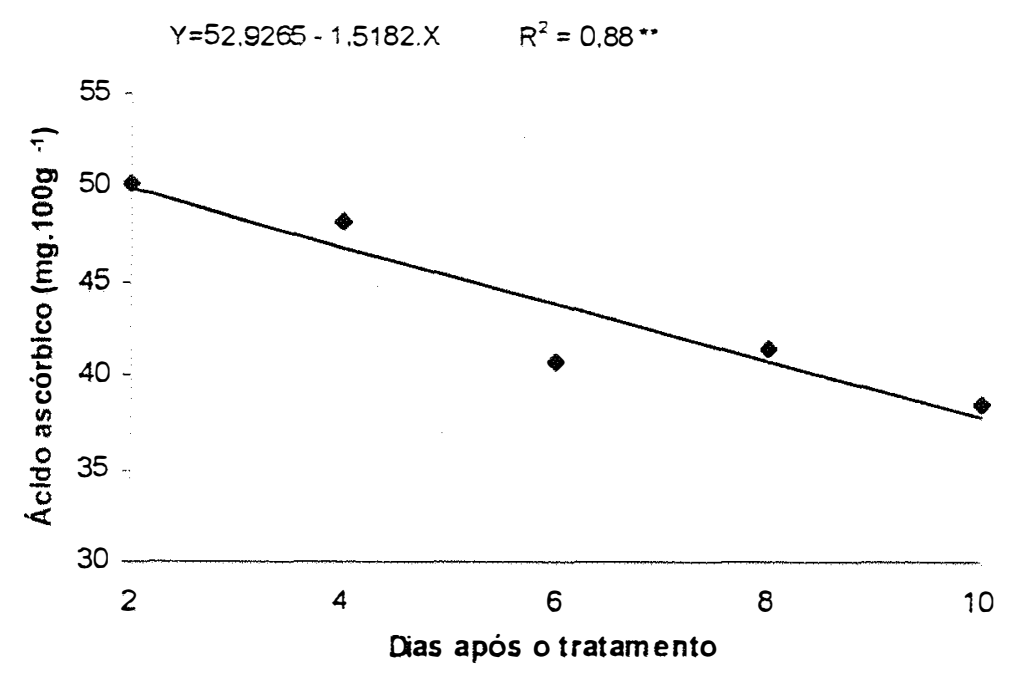

Figura 8 - Teor de ácido ascórbico de frutos de caquizeiro 'Giombo', durante o período de 10 dias subsequentes à exposição ao vapor de álcool etílico. (Análise inicial = 61,39mg.100g $\mathrm{g}^{-1}$. ESALQ, Piracicaba-SP, 1999.

Tais resultados estão de acordo com os obtidos por Montenegro \& Salibe (1959), que afirmaram que o caqui apresenta uma variação no teor de vitamina $C$ em função do grau de maturação, apresentando, os frutos verdolengos, maior conteúdo em vitamina C que os frutos maduros ou senescentes. Taira et al. (1987) obtiveram resultados semelhantes, constatando uma ligeira alteração nos teores de ácido ascórbico de frutos de caquizeiro que tiveram sua adstringência removida através do tratamento com álcool em pós-colheita. 
Ao contrário dos resultados obtidos, Montenegro \& Salibe (1959) relataram que o tratamento de frutos de caquizeiro 'Coração de Boi' com solução de ácido acético, visando a antecipação da maturação, pareceu evitar a diminuição normal do teor de vitamina $\mathrm{C}$ durante o processo de amadurecimento.

A exposição dos frutos ao vapor de álcool etílico, como um processo de antecipação da maturação, promove uma antecipação da ascensão climatérica, envolvendo um aumento na taxa respiratória (Itamura et al., 1997). Conforme relataram Chitarra \& Chitarra (1990), a respiração resulta em modificações profundas dos constituintes do fruto, dentre os quais encontram-se as vitaminas.

\section{CONCLUSÕES}

- A exposição de frutos de caquizeiro ao vapor de álcool etílico comprovou ser um método prático e eficiente no processo de destanização;

- A remoção da adstringência através do método de exposição de frutos de caquizeiro 'Giombo' ao vapor de álcool etílico pode ser realizada no período de 24 horas;

- O melhor período para consumo dos frutos situa-se entre o $4^{\circ}$ e o $8^{\circ}$ dia após o tratamento, considerando que a partir do $4^{\circ}$ dia a concentração de taninos solúveis ficou abaixo de $0,1 \%$ e a firmeza da polpa dos frutos se manteve aceitável durante o período de oito dias posteriores ao tratamento.

\section{REFERÊNCIAS BIBLIOGRÁFICAS}

BIASI, L.A.; GERHARDT, I.R. Efeito da aplicação de vinagre, álcool e ethephon na destanização de caquis cv. Okira. Revista Brasileira de Fruticultura, v.14, n.2, p.31-36, 1992. 
CAMPO-DALL'ORTO, F.A.; OJMA, M.; BARBOSA, W.; ZULLO, M.A.T. Novo processo de avaliação da adstringência dos frutos no melhoramento do caquizeiro. Bragantia, v.55, n.2, p.237-243, 1996.

CARVALHO, C.R.L.; MANTOVANI, D.M.B.; CARVALHO, P.R.N.; MORAES, R.M.M. Análises químicas de alimentos. Campinas: ITAL, 1990. 121p. (Manual Tèsnico).

CHIT ARRA, M.I.F.; CHITARRA, A.B. Pós-colheita de frutos e hortaliças: fisiologia e manuseio. Lavras: ESAL/FAEPE, 1990. 293p.

COSTA. A. N. da. Produção e qualidade dos frutos de diferentes variedades de caqui (Diospyros kaki L.), visando à industrialização. Viçosa, 1984. 50p. Dissertação (M.S.) - Universidade Federal de Viçosa.

FLKLSHIMA, T.; KITAMURA, T.; MURA YAMA, H.; YOSHIDA, T. Mechanisms of astringency removal by ethanol treatment in 'Hiratanenashi' kaki fruits. Journal of the Japanese Society for Horticultural Science, v.60, n.3, p.685-694, 1991. Resumo em CAB Abstracts on CD-ROM, 1993-1994.

ITAMLRA, H.; KITAMURA, T.; TAIRA, S.; HARADA, H.; ITO, N.; TAKAHASHI, Y.; FUKUSHIMA, T. Relationship between fruit softening, ethylene production and respiration in Japanese persimmon 'Hiratanenashi'. Journal of the Japanese Society for Horticultural Science, v.60, n.3, p.695-701, 1991. Resumo em CAB Abstracts on CD-ROM, 1993-1994.

ITAMLRA, H.; OHHO, Y.; YAMAMURA, $\mathrm{H}$. Characteristics of fruit softening in Japanese persimmon 'Saijo' Acta Horticulturae, n.436, p.179-188, 1997.

ITO, S. The persimmon. In: HULME, A.C. The biochemistry of fruits and their products. London: Academic Press, 1971. v.2, cap. 8, p.281- 301. 
KATO, K. Conditions for tanning and sugar extraction, the relationship of tannin concentration to astringency and the behaviour of ethanol during the removal of astringency by ethanol in persimmon fruits. Journal of the Japanese Society for Horticultural Science, v.53, n.2, p.127-134, 1984a. Resumo em CAB Abstracts on CD-ROM, 1984-1986.

KATO, K. Astringency removal and ripening as related to ethanol concentration in persimmon fruits. Journal of the Japanese Society for Horticultural Science, v.53, n.3, p.278-289, 1984b. Resumo em CAB Abstracts on CD-ROM, 19871989.

$\mathrm{KATO}, \mathrm{K}$. Astringency removal and ripening as related to temperature during the astringency removal by ethanol in persimmon fruits. Journal of the Japanese Society for Horticultural Science, v.55, n.4, p.498-509, 1987. Resumo em CAB Abstracts on CD-ROM, 1987-1989.

MARTINS, F.P.; PEREIRA, F.M. Cultura do caquizeiro. Jaboticabal: FUNEP, 1989. $71 \mathrm{p}$.

MONTENEGRO, H.W.S.; SALIBE, A.A. Vitamina C em caqui (Diospyros kaki L.) Revista de Agricultura, v.34, n.3, p. 183-195, 1959.

MOURA, M.A. da. Efeito da embalagem e do armazenamento no amadurecimento do caqui (Diospyros kaki L.) cultivar Taubaté. Viçosa, 1995. 84p. Dissertação (M.S.) - Universidade Federal de Viçosa.

PENTEADO, S.R. Cultura do caquizeiro. In: Fruticultura de clima temperado em São Paulo. Campinas: Fundação Cargill, 1986. cap.8, p.157-173.

PESIS, E.; LEVI, A.; BEN-ARIE, R. Deastringency of persimmon fruits by creating a modified atmosphere in polyethylene bags. Journal of Food Science, v.51, n.4, p.1014-1016, 1041, 1986. 
SUGIURA, A.; TOMANA, T. Relationships of ethanol production by seeds of different types of Japanese persimmons and their tannin content. HortScience, v.18, n.3, p.319-321, 1983.

TAIRA, S.; KUBO, Y.; SUGIURA, A.; TOMANA, T. Comparative studies of postharvest fruit quality and storage quality in Japanese persimmon (Diospyros kaki L. cv. Hiratanenashi) in relation to different methods for removal of astringency. Journal of the Japanese Society for Horticultural Science, v.56, n.2, p.215-221, 1987. Resumo em CAB Abstracts on CD-ROM, 1987-1989.

TAIRA, S.; SATOH, I.; WATANABE, S. Relationship between differences in the ease of removal of astringency among fruits of Japanese persimmon (Diospyros kaki Thunb.) and their ability to acumulate ethanol and acetaldehyde. Journal of the Japanese Society for Horticultural Science, v.60, n.4, p.1003-1009, 1992. Resumo em CAB Abstracts on CD-ROM, 1993-1994.

TIAN, J.W.; XU, M.X.; HE, P.C. Study on the physiology of postharvest softening of Diospyros kaki fruits. Plant Physiology Communications, v.2, p.109-111, 1991. Resumo em CAB Abstracts on CD-ROM, 1993-1994.

VAN BUREN, J. Fruit phenolics. In: HULME, A.C. The biochemistry of fruits and their products. London: Academic Press, 1970. v.1, p.269-304.

VIDRIH, R.; SIMCIC, M.; HRIBAR, J.; PLESTENJAK, A. Astringency removal by high $\mathrm{CO}_{2}$ treatment in persimmon fruit (Diospyros kaki). Acta Horticulturae, n.368, p.652-656, 1994.

WILLS, R.H.H.; LEE, T.H.; GRAHAM, D.; McGLASSON, W.B.; HALL, E.G. Postharvest - an introduction to the physiology and handling of fruit and vegetables. Kensington: New South Wales University Press, 1981. $161 \mathrm{p}$.

WOODS, J.L. Moisture loss from fruits and vegetables. Postharvest News and Information, v.1, n.3, p.195-199, 1990. 
4 - SEGUNDO TRABALHO CIENTÍFICO

REMOÇÃO DA ADSTRINGÊNCIA E QUALIDADE DE FRUTOS DE CAQUIZEIRO 'GIOMBO' SUBMETIDOS À EMBALAGEM DE POLIETILENO E DIFERENTES PERÍODOS DE ARMAZENAMENTO REFRIGERADO ${ }^{1}$

LUCIMARA ROGÉRIA ANTONIOLLI ${ }^{2}$ E PAULO ROBERTO DE CAMARGO E CASTRO $^{3}$

\footnotetext{
${ }^{1}$ Parte da Dissertação de Mestrado em Fisiologia e Bioquímica de Plantas do primeiro autor.

${ }^{2}$ Pós-graduanda em Fisiologia e Bioquímica de Plantas. ESALQ - USP, Piracicaba (SP).

${ }^{3}$ Prof. Titular do Deparamento de Ciências Biológicas. ESALQ - USP, Piracicaba (SP).
} 


\section{REMOÇĀO DA ADSTRINGÊNCIA E QUALDADE DE FRUTOS DE CAQUIZEIRO 'GIOMBO' SUBMETWOS À EMBALAGEM DE POLIETILENO E DIFERENTES PERÍODOS DE ARMAZENAMENTO REFRIGERADO}

\section{RESUMO}

No presente trabalho, procurou-se estudar o efeito da utilização de embalagem de polietileno no acondicionamento de frutos de caquizeiro (Diospyros kaki L.) cultivar Giombo durante o armazenamento refrigerado e a qualidade dos frutos submetidos ao processo de remoção da adstringência, mediante a exposição ao vapor de álcool etílico, após a refrigeração. Os frutos, embalados ou não em sacos de polietileno $(0,06 \mathrm{~mm})$ foram mantidos em câmara refrigerada durante diferentes períodos (30, 60 ou 90 dias), a $1^{\circ} \mathrm{C}$ e $95-98 \%$ UR. Ao término de cada período de armazenamento os frutos foram expostos ao vapor de etanol durante 40 horas, a $20^{\circ} \mathrm{C}$ e $95 \%$ UR. As características químicas e fisicas dos frutos foram avaliadas ao final de cada período de armazenamento e após a destanização, durante 6 dias, em intervalos de 3 dias. As variáveis analisadas foram: teor de taninos solúveis, firmeza da polpa, perda de matéria fresca, $\mathrm{pH}$, sólidos solúveis totais, acidez total titulável e teor de ácido ascórbico. De acordo com os resultados obtidos, os frutos mantiveram elevada qualidade durante os primeiros 30 dias de armazenamento, apresentando aos 60 dias, redução na qualidade comercial decorrente da aparência pouco atrativa e da baixa firmeza de polpa. A utilização da embalagem de polietileno $(0,06 \mathrm{~mm})$ não apresentou eficiência na remoção total da adstringência dos frutos, havendo necessidade de um tratamento adicional para completar a destanização. Frutos armazenados por 30 dias e submetidos ao vapor de álcool etílico tormaram-se não adstringentes após três dias do tratamento, no entanto, a firmeza insuficiente da polpa associada à elevada perda de matéria fresca tornou os frutos pouco aceitáveis comercialmente.

Palavras-chave: Diospyros kaki, polietileno, tanino, etanol. 


\title{
ASTRINGENCY REMOVAL AND QUALITY OF 'GIONBO' PERSIMMON FRUITS SUBMITTED AT POLYETHYLENE BAGS AND DIFFERENT PERIODS OF COLD STORAGE
}

\begin{abstract}
The purpose of this research was to study the effect of polyethylene bags in the packing of persimmon fruits (Diospyros kaki L.) cultivar Gionbo during the cold storage and the quality of fruits submitted at astringency removal process through the exposure to ethanol vapor after the cold storage. Packed fruits in polyethylene bags $(0.06 \mathrm{~mm})$ and non-packed fruits were kept in cold room during different periods (30, 60 or 90 days) at $1^{\circ} \mathrm{C}$ and $95-98 \% \mathrm{RH}$. Fruits were exposed to ethanol vapor for 40 hours at $20^{\circ} \mathrm{C}$ and $95 \% \mathrm{RH}$ at the end of each storage period. Chemical and physical characteristics of fruits were measured at the end of each storage period and after the deastringency process, during 6 days, at 3 days intervals. Soluble tannin content, flesh firmness, water loss, $\mathrm{pH}$, soluble solids, titratable acidity and ascorbic acid content were measured. This research showed that fruits kept high quality during 30 days of storage and showed decrease in the commercial quality after 60 days of cold storage, resulting from not enough attractive appearance and low firmness of the flesh. The use of polyethylene bags $(0.06 \mathrm{~mm})$ did not completely remove the fruits astringency, which were submitted at additional treatment for astringency removal. Fruits in storage for 30 days and submitted at ethanol vapor became non-astringents 3 days after the treatment, although the insufficient firmness of the flesh associated to high water loss resulted in fruits not enough acceptable commercially.
\end{abstract}

Key words: Diospyros kaki, polyethylene, tannin, ethanol. 


\section{INTRODUÇÃO}

A cultura do caquizeiro (Diospyros kaki L.) possui elevada importância econômica no Brasil, estando estabelecida nas regiões Sul e Sudeste, onde ocorrem condições climáticas favoráveis ao seu desenvolvimento (Brackmann \& Saquet, 1995).

O cultivar Giombo é classificado por Ito (1971), como pertencente ao tipo PCA (frutos que não apresentam mudança na coloração da polpa em função da polinização e adstringentes), no entanto, Martins \& Pereira (1989) classificam este cultivar como pertencente ao tipo variável, apresentando frutos com polpa bastante taninosa quando partenocárpicos e do tipo "chocolate" e, portanto, sem adstringência quando com numerosas sementes.

A maturação dos frutos ocorre de fevereiro a maio, sendo que fora desse periodo há escassez do produto no mercado (Brackmann \& Saquet, 1995), decorrente do próprio ciclo da cultura e da carência de tecnologia adequada à conservação dos frutos.

O armazenamento refrigerado destaca-se como uma possibilidade no prolongamento da vida pós-colheita dos frutos, refletindo na dilatação do período de comercialização. A conservação dos frutos é dependente do ponto de maturação, do cultivar e das condições de temperatura e umidade relativa das câmaras (Martins \& Pereira, 1989). De maneira geral, os caquis se conservam melhor sob condições de 90$100 \%$ de umidade relativa e temperatura de $1^{\circ} \mathrm{C}$ (Ito, 1971; Lyon et al., 1992).

A utilização de embalagens de polietileno, visando a conservação dos frutos, promove uma modificação na atmosfera ao redor destes, devido à respiração do produto, que eleva a concentração de $\mathrm{CO}_{2}$ e diminui a concentração de $\mathrm{O}_{2}$ (Pesis et al., 1986). Com o aumento do $\mathrm{CO}_{2}$ ocorre redução na síntese e na ação do etileno, hormônio responsável pelo amadurecimento de frutos climatéricos, como o caqui (Chitarra \& Chitarra, 1990).

Frutos de caquizeiro 'Giombo' acondicionados em sacos de polietileno com espessura de $0,08 \mathrm{~mm}$ e mantidos à temperatura de $0^{\circ} \mathrm{C}$ puderam ser conservados 
durante um periodo de 2 meses, enquanto os mantidos sob atmosfera normal a $0^{\circ} \mathrm{C}$ e 90\% UR foram conservados somente durante 6 semanas (Martins \& Pereira, 1989).

Pekmezci et al. (1997) relataram um experimento em que frutos de caquizeiro 'Fuyu' puderam ser armazenados durante um período de 5 a 6 meses a $0^{\circ} \mathrm{C}$ quando acondicionados, individualmente, em embalagem de polietileno com espessura de 0,06 mm. De forma semelhante, Lee \& Yang (1997) constataram menor ocorrência de desordens fisiológicas e melhor qualidade de frutos de caquizeiro 'Fuyu' acondicionados em filme de polietileno de $0,05 \mathrm{~mm}$, durante um período de 90 dias de armazenamento.

Vidrih et al. (1994) citaram que frutos de caquizeiro mantidos sob atmosfera com alta concentração de $\mathrm{CO}_{2}$ acumulam elevadas concentrações de etanol e acetaldeído, como resultado das modificações no processo respiratório. $\mathrm{O}$ acetaldeído formado durante o tratamento pode reagir com os taninos solúveis causando sua polimerização e tornando-os insolúveis (Ito, 1971). No entanto, Moura et al. (1997) indicaram a necessidade de indução ao amadurecimento de frutos de caquizeiro 'Taubaté', que mantiveram o teor de tanino e o grau de adstringência constantes, mesmo com a utilização de embalagem, durante o período de 72 dias de armazenamento a $0^{\circ} \mathrm{C}$.

De acordo com Penteado (1986), vários são os produtos possíveis de serem utilizados na remoção da adstringência do caqui, como álcool, vinagre, água de cal, etileno e carbureto de cálcio. Tais tratamentos estimulam o acúmulo de compostos voláteis na polpa dos frutos, como etanol e acetaldeído, e estas substâncias, especialmente $\mathrm{o}$ acetaldeído, induzem os taninos solúveis a se polimerizarem e formarem complexos insolúveis, resultando, com isso, na perda da adstringência (Sugiura \& Tomana, 1983).

Segundo constatações de Biasi \& Gerhardt (1992), frutos de caquizeiro 'Okira' tratados com álcool apresentaram resistência de polpa superior à dos frutos tratados com vinagre e ethephon, após o processo de destanização. Este resultado confirmou as observações de Martins \& Pereira (1989), que citaram o álcool como um agente destanizador que possibilitou a obtenção de frutos com polpa firme após o processo. 
Pesis et al. (1986) associaram o início do amolecimento da polpa de frutos de caquizeiro 'Triumph' ao valor de firmeza de $4,2 \mathrm{~kg} . \mathrm{cm}^{-2}$.

Conforme observações de Fukushima et al. (1991), o tratamento com etanol proporcionou maior rapidez no processo de perda da adstringência em caquis 'Hiratanenashi' quando comparado ao tratamento com acetaldeído. Quando realizado sob temperaturas de 15 ou $20^{\circ} \mathrm{C}$, tal tratamento possibilitou a manutenção da qualidade dos frutos por um periodo igual ou superior a 10 dias (Kato, 1987).

O objetivo deste trabalho foi avaliar o efeito da utilização da embalagem de polietileno no decorrer de diferentes periodos de armazenamento refrigerado, bem como avaliar a qualidade dos frutos submetidos ao processo de remoção da adstringência, mediante a exposição ao vapor de álcool etílico, ao término de cada período de armazenamento.

\section{MATERIAL E MÉTODOS}

Os frutos de caquizeiro 'Giombo' foram colhidos no mês de maio de 1998, em pomar comercial localizado no municipio de Guapiara, São Paulo, situado a $24^{\circ} 11^{\prime}$ de latitude Sul e $48^{\circ} 02^{\prime}$ de longitude Oeste e a 900 metros de altitude, com clima do tipo $\mathrm{Cfb}$, segundo Köppen.

Em função da colheita tardia, considerando-se que o período de colheita, para este cultivar, inicia-se no mês de março e estende-se até fins de maio (Martins \& Pereira, 1989), os frutos apresentavam coloração $100 \%$ alaranjada e bastante uniforme.

Os frutos foram transportados ao Laboratório de Fisiologia Pós-Colheita do Departamento de Ciências Biológicas da Escola Superior de Agricultura "Luiz de Queiroz", onde se realizou rigorosa seleção, visando a padronização dos frutos com relação ao tamanho, bem como a eliminação dos frutos com qualidade inferior à desejada. 
Foram selecionados 270 frutos e imediatamente acondicionados em bandejas de isopor (144 x $208 \mathrm{~mm}$ ), totalizando 54 bandejas, contendo 5 frutos cada uma. Deste total, 27 bandejas foram envoltas por embalagem de polietileno com espessura de 0,06 $\mathrm{mm}$ e as demais permaneceram sem embalagem. Todos os frutos foram mantidos em câmara refrigerada à temperatura de $1^{\circ} \mathrm{C}$, com umidade relativa variando entre $95 \mathrm{e}$ $98 \%$.

Foram retiradas da refrigeração 18 bandejas a cada 30 dias, durante um periodo de 90 dias, sendo 9 delas com e as demais sem embalagem de polietileno. Destas 9 parcelas, 3 foram avaliadas quanto às suas características fisicas e químicas, enquanto que os frutos das demais foram destanizados mediante exposição, por 40 horas, ao vapor de álcool etílico hidratado $92,8^{\circ}$ INPM (álcool comercial). Para tal foram utilizadas câmaras B.O.D. (Biologic Oxygen Demand, Modelo TE 390-Tecnal) contendo 3,85 ml de álcool / $\mathrm{L}$ câmara $\left(3,85 \mathrm{~L} \cdot \mathrm{m}^{-3}\right)$. Durante o processo, a temperatura foi mantida a $20^{\circ} \mathrm{C}$ e a umidade relativa em torno de $95 \%$.

Terminado o periodo de exposição, os frutos foram retirados das câmaras e colocados em bancadas de laboratório, à temperatura ambiente $\left(24-25^{\circ} \mathrm{C}\right)$

As características químicas e fisicas dos frutos foram avaliadas em intervalos de três dias, durante o período de seis dias.

As variáveis analisadas foram: a) teor de taninos solúveis ( $\left.\mathrm{g} \cdot 100 \mathrm{~g}^{-1} \mathrm{polpa}\right)$ : determinado espectrofotometricamente utilizando-se o reagente de Follin-Denis, segundo técnica recomendada por Carvalho et al. (1990), onde uma amostra de $5 \mathrm{~g}$ de polpa triturada e homogeneizada foi diluida para um volume final de $100 \mathrm{ml}$ com água destilada do qual se retirou uma alíquota de $5 \mathrm{ml}$. A esta alíquota se adicionou reagente de Follin-Denis e solução de carbonato de sódio, completando o volume a $100 \mathrm{ml}$ com água destilada. Após um período de 30 minutos, a solução foi filtrada e em seguida determinou-se a absorbância a $760 \mathrm{~nm}$. Foi utilizada, como padrão, uma solução de ácido tânico $\left(0,1 \mathrm{~g} \cdot \mathrm{L}^{-1}\right)$; b) firmeza de polpa $\left(\mathrm{kg} . \mathrm{cm}^{-2}\right)$ : medida com penetrômetro EFFEGI, com ponteira de $6,5 \mathrm{~mm}$ de diâmetro, efetuando-se duas leituras em lados opostos na 
região equatorial dos frutos, após a remoção de uma pequena área da casca. Associou-se o início do amolecimento da polpa ao valor de firmeza de $5 \mathrm{~kg} . \mathrm{cm}^{-2}$; c) perda de matéria fresca (\%): avaliada durante o armazenamento nas datas pré-estabelecidas e calculada pela diferença entre as massas inicial e final, sendo apresentada como porcentagem da massa inicial. Avaliada no processo de remoção da adstringência durante o tratamento nas câmaras B.O.D. e durante 6 dias após o tratamento, em intervalos de 3 dias; d) pH: medido por potenciometria em amostra triturada e homogeneizada; e) sólidos solúveis totais ( ${ }^{\circ} \mathrm{Brix}$ ): determinado por refratometria, com correção de temperatura para $20^{\circ} \mathrm{C} ; \mathrm{f}$ ) acidez total titulável (\% ácido málico): determinada através da diluição de $10 \mathrm{ml}$ da amostra em $90 \mathrm{ml}$ de água destilada, e posterior titulação com solução de $\mathrm{NaOH}$ a $0,1 \mathrm{~N}$, até $\mathrm{o} \mathrm{pH}$ de 8,$10 ; \mathrm{g}$ ) teor de ácido ascórbico (mg ácido ascórbico. $100 \mathrm{~g}^{-1}$ polpa): determinado segundo metodologia de Carvalho et al. (1990), a qual se baseia na redução do indicador 2,6-diclorobenzenoindofenol (DCFI) pelo ácido ascórbico.

O delineamento experimental adotado, para o armazenamento, foi 0 inteiramente casualizado, com 6 tratamentos provenientes de um fatorial $2 \times 3$. Os fatores estudados foram: com e sem embalagem de polietileno e 3 tempos de amostragem (30,60 e 90 dias). A cada avaliação foram utilizadas 3 repetições com 5 frutos por parcela.

Para a análise do processo de destanização dos frutos adotou-se o delineamento inteiramente casualizado, com 4 tratamentos provenientes de um fatorial $2 \times 2$. Os fatores estudados foram: com e sem embalagem de polietileno durante o armazenamento e 2 tempos de amostragem ( 3 e 6 dias). A cada avaliação foram utilizadas 3 repetições com 5 frutos por parcela.

Os dados coletados foram submetidos à análise de variância e as médias comparadas pelo teste de Tukey ao nível de $5 \%$ de probabilidade.

Uma amostra representativa dos frutos foi submetida à uma avaliação prévia ao armazenamento, objetivando a caracterização inicial dos mesmos. 


\section{RESULTADOS E DISCUSSÃO}

\section{Armazenamento refrigerado}

Na Tabela 1 encontra-se resumida a análise da variância dos efeitos dos tratamentos sobre as diversas variáveis analisadas no experimento. Observa-se que houve efeito da utilização de embalagem bem como do período de armazenamento sobre a maioria das variáveis analisadas.

Tabela 1 - Análise de variância dos efeitos da utilização de embalagem e de diferentes períodos de armazenamento sobre as variáveis analisadas em frutos de caquizeiro 'Giombo'. ESALQ, Piracicaba-SP, 1999.

\begin{tabular}{|c|c|c|c|c|c|c|c|}
\hline \multirow[b]{2}{*}{$\begin{array}{c}\text { Efeitos principais } \\
\text { e interação }\end{array}$} & \multicolumn{7}{|c|}{ Variáveis analisadas ${ }^{\mathrm{x}}$} \\
\hline & TS & FP & PMF & $\mathrm{pH}$ & SST & ATT & $\mathrm{AA}$ \\
\hline & --- & -------- & ---Signif & ância d & este F- & ------- & ---- \\
\hline Embalagem (E) & $*$ & $*$ & $* *$ & n.s. & $* *$ & n.s. & n.s. \\
\hline \multicolumn{8}{|l|}{ Período de } \\
\hline Armazenamento (PA) & n.s. & $* *$ & $* *$ & $* *$ & $* *$ & $* *$ & n.s. \\
\hline$E \times P A$ & n.s. & n.s. & $* *$ & n.s. & $* *$ & $*$ & n.s. \\
\hline C.V. $(\%)$ & 26,87 & 18,65 & 12,82 & 1,66 & 2,13 & 21,28 & 13,86 \\
\hline
\end{tabular}




\section{Taninos solúveis}

Verifica-se na Tabela 2 que a utilização de embalagem durante 0 armazenamento refrigerado proporcionou o menor teor médio de taninos solúveis, que diferiu significativamente daquele constatado nos frutos sem embalagem.

$\mathrm{O}$ acondicionamento dos frutos em embalagem de polietileno propicia $\mathrm{O}$ desenvolvimento de um ambiente com alta concentração de dióxido de carbono (Pesis et al., 1986), o que conduz ao acúmulo de elevadas concentrações de etanol e acetaldeído, como resultado das modificações no processo respiratório (Vidrih et al., 1994). O acetaldeído formado pode reagir com os taninos solúveis causando sua polimerização e tornando-os insolúveis (Ito, 1971).

Hong et al. (1993) obtiveram frutos destanizados após 44 dias de armazenamento sob temperaturas de 0 a $3^{\circ} \mathrm{C}$, quando utilizaram embalagens de polietileno com espessura de 0,08 $\mathrm{mm}$. No entanto, Awad \& Amenomori (1971) relataram que o confinamento de frutos de caquizeiro 'Taubaté' em sacos de polietileno não apresentou efeito algum sobre a destanização dos frutos, possivelmente devido à pouca espessura da embalagem, o que resultou em uma permeabilidade muito alta e em baixo acúmulo de $\mathrm{CO}_{2}$.

Verificou-se, neste experimento, que a utilização de embalagem de polietileno comprovou ser eficiente no estabelecimento de ambiente favorável à polimerização dos taninos solúveis, muito embora a espessura de $0,06 \mathrm{~mm}$ talvez não seja a mais indicada, considerando-se que o teor médio de $0,24 \%$ de taninos solúveis ainda proporciona frutos adstringentes (Kato, 1984).

Embora o teor de taninos solúveis não tenha sido alterado significativamente durante todo o periodo de armazenamento, constatou-se, que após 30 dias, o teor de taninos foi inferior àquele verificado na caracterização inicial dos frutos, correspondente a $0,53 \mathrm{~g} \cdot 100 \mathrm{~g}^{-1}$. O teor médio de taninos solúveis sofreu um decréscimo até o término do período de 60 dias, atingindo o teor de $0,26 \mathrm{~g} \cdot 100 \mathrm{~g}^{-1}$, quando então permaneceu constante até o final do armazenamento (Tabela 2). 
Tabela 2 - Efeito da embalagem de polietileno e do período de armazenamento sobre as variáveis analisadas em frutos de caquizeiro 'Giombo' armazenados à temperatura de $1^{\circ} \mathrm{C}$. ESALQ, Piracicaba-SP, 1999.

\begin{tabular}{|c|c|c|c|}
\hline \multirow{2}{*}{$\begin{array}{l}\text { Período } \\
\text { (dias) }\end{array}$} & \multicolumn{2}{|c|}{ Embalagem de polietileno } & \multirow[t]{2}{*}{ Média } \\
\hline & Com & Sem & \\
\hline \multicolumn{4}{|c|}{ - Taninos solúveis $\left(\mathrm{g} .100 \mathrm{~g}^{-1}\right) \ldots$} \\
\hline 30 & 0,24 & 0,45 & $0.35 \mathrm{a}$ \\
\hline 60 & 0.23 & 0,30 & $0.26 \mathrm{a}$ \\
\hline 90 & 0.24 & 0.28 & $0,26 \mathrm{a}$ \\
\hline Média & $0.24 \mathrm{~B}$ & $0,35 \mathrm{~A}$ & - \\
\hline \multicolumn{4}{|c|}{ Firmeza $\left(\mathrm{kg}_{\mathrm{cm}} \mathrm{cm}^{-2}\right) \ldots$} \\
\hline 30 & 9,21 & 9,99 & $9.6 \mathrm{a}$ \\
\hline 60 & 4,37 & 5,97 & $5.17 \mathrm{~b}$ \\
\hline 90 & 2,15 & 3,97 & $3.06 \mathrm{c}$ \\
\hline Média & $5.24 \mathrm{~B}$ & $6,64 \mathrm{~A}$ & - \\
\hline \multicolumn{4}{|c|}{-- Perda de matéria fresca (\%) - - } \\
\hline 30 & 0,07 a B & $2.98 \mathrm{CA}$ & 1.53 \\
\hline 60 & 0.16 a B & $5,56 \mathrm{~b} \mathrm{~A}$ & 2.86 \\
\hline 90 & 0.27 a B & 8.09 a $\mathrm{A}$ & 4,18 \\
\hline Média & 0.17 & 5,55 & - \\
\hline 30 & 5.84 & 5,78 & $5.81 \mathrm{~b}$ \\
\hline 60 & 6.03 & 6.08 & $6,06 \mathrm{a}$ \\
\hline 90 & 5,90 & 5,93 & $5.91 \mathrm{ab}$ \\
\hline Média & $5.92 \mathrm{~A}$ & $5,93 \mathrm{~A}$ & - \\
\hline \multicolumn{4}{|c|}{$-\operatorname{SST}\left({ }^{\circ} \mathrm{Brix}\right)-$} \\
\hline 30 & 18.27 a B & 20,40 a A & 19.33 \\
\hline 60 & 18,37 a $\mathrm{A}$ & $18,37 \mathrm{CA}$ & 18,34 \\
\hline 90 & 18,84 a $\mathrm{A}$ & 19,27 b A & 19.05 \\
\hline Média & 18,49 & 19,32 & - \\
\hline \multicolumn{4}{|c|}{-._. ATT (\% ácido málico) } \\
\hline 30 & $0,1027 \mathrm{~b} \mathrm{~A}$ & 0,1161 a $A$ & 0,1094 \\
\hline 60 & $0,0782 \mathrm{~b} \mathrm{~A}$ & 0,0815 a $\mathrm{A}$ & 0,0798 \\
\hline 90 & 0,1742 a $A$ & 0,1139 a $B$ & 0,1441 \\
\hline Média & 0,1184 & 0,1038 & - \\
\hline \multicolumn{4}{|c|}{-... Ácido ascórbico (mg.100 $\left.\mathrm{g}^{-1}\right)$} \\
\hline 30 & 46,55 & 43,96 & $45,26 \mathrm{a}$ \\
\hline 60 & 47,49 & 41,41 & $44,45 \mathrm{a}$ \\
\hline 90 & 43,39 & 46,03 & $44,71 \mathrm{a}$ \\
\hline Média & $45,81 \mathrm{~A}$ & $43,80 \mathrm{~A}$ & - \\
\hline
\end{tabular}

Para cada variável, as médias seguidas pela mesma letra minúscula na coluna e mesma letra maiúscula na linha não diferem significativamente entre si pelo teste de Tukey ao nível de $5 \%$ de probabilidade. (Análise inicial: tanino $=0,53 \mathrm{~g} \cdot 100 \mathrm{~g}^{-1}$; firmeza $=10,07 \mathrm{~kg} \mathrm{~cm}^{-2} ; \mathrm{pH}=5,99 ; \mathrm{SST}=19,69^{\circ} \mathrm{Brix} ; \mathrm{ATT}=$ $0,1027 \%$ ácido málico; ácido ascórbico $=32,48 \mathrm{mg} \cdot 100 \mathrm{~g}^{-1}$ ). 
De acordo com constatações de Kato (1984), frutos contendo aproximadamente $0,25 \%$ de tanino revelam-se ligeiramente adstringentes, tornando-se comestíveis quando a concentração de taninos solúveis encontra-se abaixo de $0,1 \%$ (Vidrih et al., 1994). Tomando-se por base os teores de taninos solúveis encontrados ao final de cada período de armazenamento associados às avaliações degustativas, verificou-se que os frutos encontravam-se, mesmo ao final do periodo de 90 dias, ainda adstringentes, necessitando, portanto, de um tratamento para remoção da adstringência.

Os resultados obtidos estão de acordo com Moura et al. (1997), que relataram que a utilização de embalagem durante 72 dias de armazenamento não foi suficiente para reduzir o teor de taninos e o grau de adstringência dos frutos de caquizeiro 'Taubaté', havendo a necessidade de indução ao amadurecimento para que ocorresse maturação homogênea dos frutos.

\section{Firmeza de polpa}

Observa-se na Tabela 2, que a utilização de embalagem interferiu sobre a firmeza da polpa dos frutos, sendo que aqueles que permaneceram sem embalagem durante o periodo de armazenamento refrigerado apresentaram maior valor médio de

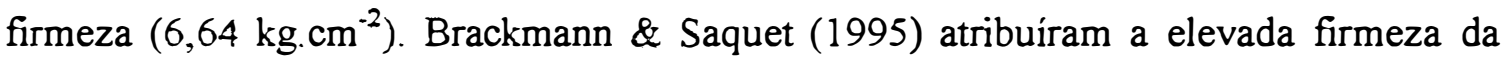
polpa de frutos de caquizeiro 'Taubaté' verificada ao final do período de 85 dias, sob atmosfera normal e temperaturas de $-0,5$ e $0,5^{\circ} \mathrm{C}$, ao murchamento dos frutos, o que conferiu maior resistência à penetração da ponteira do penetrômetro.

Houve uma diminuição na firmeza da polpa dos frutos com o aumento do período de conservação (Tabela 2), atingindo o valor médio de $3,06 \mathrm{~kg}_{\mathrm{cm}} \mathrm{cm}^{-2}$ ao final de 90 dias, o que caracteriza frutos inaceitáveis para o consumo, uma vez que os frutos deste cultivar são consumidos com polpa firme. Ao final do período de 60 dias, os frutos ainda apresentaram firmeza de polpa aceitável para consumo.

Tais resultados estão de acordo com Turk (1993), que constatou uma diminuição na firmeza da polpa de frutos de caquizeiro durante o amazenamento 
refrigerado, com perda da qualidade de comercialização após um período de 40-60 dias do início do armazenamento.

Pekmezci et al. (1997) relataram um experimento em que, de maneira semelhante, constatou-se que o amolecimento dos frutos de caquizeiro 'Fuyu' foi um fator limitante durante o armazenamento refrigerado.

Considerando-se que a firmeza da polpa dos frutos anterior ao armazenamento era de $10,07 \mathrm{~kg} . \mathrm{cm}^{-2}$, constata-se que houve uma perda de cerca de $70 \%$ da firmeza dos frutos ao final do periodo de armazenamento.

\section{Perda de matéria fresca}

Verifica-se na Tabela 2, que a utilização de embalagem protegeu os frutos contra a perda de matéria fresca, que não diferiu significativamente durante o periodo de armazenamento. Os frutos sem embalagem, apresentaram uma perda de matéria fresca crescente durante o periodo de armazenamento, atingindo o valor de $8,09 \%$ ao final do periodo de 90 dias. Observa-se que os frutos desprovidos de embalagem apresentaram perdas de matéria fresca sempre superiores àquelas constatadas nos frutos embalados.

Os resultados obtidos estão de acordo com os apresentados por Moura et al. (1997), que constataram uma crescente perda de matéria fresca nos frutos de caquizeiro durante o período de 72 dias de armazenamento refrigerado a que foram submetidos, sendo esta perda reduzida nos frutos embalados com película de PVC. De acordo com Pesis et al. (1986), a menor perda de matéria fresca verificada nos frutos embalados é decorrente da alta umidade relativa no interior da embalagem, que reduz o déficit de pressão de vapor e, consequentemente, a transpiração dos frutos.

\section{Potencial hidrogeniônico (pH)}

Os dados apresentados na Tabela 2 indicam que o fator embalagem não interferiu sobre o valor de $\mathrm{pH}$ da polpa, o que foi observado, de forma semelhante, por 
Moura (1995) que afirmou que os frutos embalados ou não com película de PVC apresentaram valores de $\mathrm{pH}$ da polpa semelhantes, durante 72 dias de armazenamento a $0^{\circ} \mathrm{C}$.

Com relação aos períodos de armazenamento, verificou-se o maior valor de $\mathrm{pH}$ aos 60 dias, o qual diferiu significativamente do valor constatado aos 30 dias, enquanto que o período de 90 dias não diferiu dos demais.

\section{Sólidos solúveis totais}

Verifica-se na Tabela 2, que o teor de sólidos solúveis totais nos frutos embalados não diferiu significativamente durante o período de armazenamento. De forma semelhante, Hong et al. (1993) constataram que frutos de cultivares adstringentes não apresentaram alteração no teor de sólidos solúveis após 44 dias de armazenamento, sob temperaturas de 0 a $3^{\circ} \mathrm{C}$, quando embalados com filme de polietileno com espessura de $0,08 \mathrm{~mm}$. Constata-se, no presente experimento, que os frutos sem embalagem diferiram significativamente ao longo do periodo de armazenamento, apresentando, após 30 dias, um ligeiro aumento no teor de sólidos solúveis quando comparado ao teor

médio obtido anteriormente ao armazenamento $\left(19,69^{\circ} \mathrm{Brix}\right)$. Verificou-se, que após este período houve um decréscimo no teor de sólidos solúveis totais, constatando-se, ao final

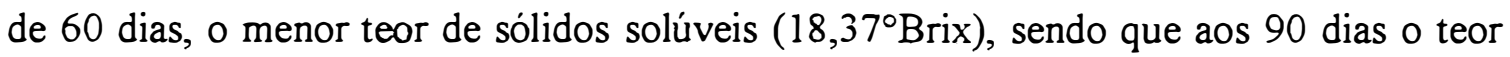
observado foi intermediário aos constatados anteriormente.

Com relação aos periodos de armazenamento, nota-se que houve diferença significativa entre os frutos com e sem embalagem somente ao final do primeiro período de armazenamento, quando verificou-se um teor de sólidos solúveis superior nos frutos sem embalagem, possivelmente em função da perda de água por transpiração, mais evidente nestes frutos. 


\section{Acidez total titulável}

A Tabela 2 mostra que a utilização da embalagem promoveu variação significativa na acidez somente ao final do periodo de 90 dias de armazenamento. Moura et al. (1997), no entanto, concluiram que a utilização de embalagem de PVC não interferiu significativamente sobre a acidez durante o armazenamento dos frutos.

O comportamento da acidez total titulável apresentado pelos frutos com embalagem durante o periodo de armazenamento parece confirmar o comportamento dos valores médios de $\mathrm{pH}$ no decorrer do armazenamento refrigerado.

Com relação aos periodos de armazenamento, verifica-se que não houve diferença significativa entre os frutos com e sem embalagem durante os dois primeiros períodos de armazenamento, no entanto, ao final de 90 dias, os frutos embalados apresentaram um valor de acidez estatisticamente superior aos frutos sem embalagem.

\section{Ácido ascórbico}

Os dados apresentados na Tabela 2 indicam que tanto o fator embalagem quanto o periodo de armazenamento não interferiram sobre o teor de ácido ascórbico da polpa dos frutos.

Embora não tenha havido diferença significativa entre os teores médios de ácido ascórbico, verificou-se que tais valores foram superiores ao valor médio obtido na caracterização inicial dos frutos, correspondente a $32,48 \mathrm{mg} \cdot 100 \mathrm{~g}^{-1}$. Ao contrário dos resultados obtidos neste experimento, Turk (1993) constatou uma diminuição no teor de vitamina $\mathrm{C}$ durante o armazenamento de frutos de caquizeiro 'Fuyu' embalados em sacos de polietileno com espessura de $0,03 \mathrm{~mm}$ e mantidos sob temperatura de $1^{\circ} \mathrm{C}$ e $90 \%$ de umidade relativa. 
Remoção da adstringência após 30 dias de armazenamento refrigerado

$\mathrm{Na}$ Tabela 3 encontra-se resumida a análise da variância dos efeitos dos tratamentos sobre as diversas variáveis analisadas no experimento. Observa-se que não houve efeito da utilização de embalagem durante o armazenamento sobre a maioria das variáveis, com exceção da perda de matéria fresca. Verifica-se, entretanto, que a interação entre utilização de embalagem durante o armazenamento e periodo de avaliação não apresentou efeito sobre nenhuma das variáveis analisadas.

Tabela 3 - Análise de variância dos efeitos da utilização de embalagem durante o armazenamento refrigerado e do período de avaliação sobre as variáveis analisadas em frutos de caquizeiro 'Giombo'. ESALQ, Piracicaba-SP, 1999.

\begin{tabular}{ccccccccc}
\hline & \multicolumn{8}{c}{ Variáveis analisadas $^{\mathrm{x}}$} \\
\cline { 2 - 7 } $\begin{array}{c}\text { Efeitos principais } \\
\text { e interação }\end{array}$ & TS & FP & PMF $^{1}$ & PMF $^{2}$ & pH & SST & ATT & AA \\
\hline
\end{tabular}

Significância do teste $F$

Embalagem durante

armazenamento (E) n.s. $\quad$ n.s. $\quad * * \quad * \quad$ n.s. $\quad$ n.s. $n . s . \quad$ n.s.

Periodo de avaliação (PA)

n.s. n.s.

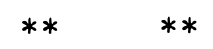

n.s.

n.s.

$E \times P A$

n.s. n.s. - n.s.

n.s.

n.s.

n.s. n.s.

C.V. $(\%)$

$7,21 \quad 20,92$

9,82

7,01

1,05

3,85

4,83

9,89

${ }^{\mathrm{T}} \mathrm{TS}=$ taninos solúveis; FP = firmeza de polpa; $\mathrm{PMF}^{1}=$ perda de matéria fresca durante o tratamento; $\mathrm{PMF}^{2}$ = perda de matéria fresca durante o período de avaliação; $\mathrm{pH}=$ potencial hidrogeniônico; $\mathrm{SST}=$ sólidos solúveis totais; $\mathrm{ATT}=$ acidez total titulável; $\mathrm{AA}=$ ácido ascórbico.

n.s.; ${ }^{* *} ;{ }^{*}$ = não significativo; significativo ao nivel de 1 e $5 \%$ de probabilidade, respectivamente. 


\section{Taninos solúveis}

A utilização de embalagem durante o período de 30 dias de armazenamento não interferiu sobre o teor de taninos solúveis da polpa dos frutos após o processo de remoção da adstringência mediante a exposição ao vapor de álcool etílico (Tabela 4). Embora o teor de taninos solúveis dos frutos armazenados sem embalagem, verificado ao término do armazenamento, tenha sido bastante superior ao dos frutos embalados $\left(0,45\right.$ e 0,24 g. $100 \mathrm{~g}^{-1}$, respectivamente), verificou-se, que durante a destanização, os frutos provenientes de ambos os tratamentos atingiram teores muito próximos, que não diferiram estatisticamente entre si.

Tais resultados estão de acordo com os obtidos por Moura (1995), que constatou teores de taninos solúveis estatisticamente semelhantes para frutos armazenados com ou sem embalagem e submetidos posteriormente, à aplicação de ethephon, como um método de indução ao amadurecimento.

Pode-se constatar na Tabela 4, que não houve diferença significativa entre os periodos de 3 e 6 dias posteriores à exposição dos frutos ao vapor de álcool etílico. Verificou-se que a adstringência dos frutos constatada ao término do armazenamento foi reduzida a niveis não detectáveis ao paladar 3 dias após o tratamento, considerando que os frutos tornam-se comestiveis somente quando a concentração de taninos solúveis encontra-se abaixo de $0,1 \%$ (Vidrih et al., 1994), o que foi confirmado através de avaliações degustativas. 
Tabela 4 - Efeito da embalagem de polietileno durante o armazenamento e do período de avaliação após a remoção da adstringência sobre as variáveis analisadas em frutos de caquizeiro 'Giombo' armazenados por 30 dias a $1^{\circ} \mathrm{C}$ e 95-98\% UR. ESALQ, Piracicaba-SP, 1999.

\begin{tabular}{|c|c|c|c|}
\hline \multirow{2}{*}{$\begin{array}{c}\text { Período de } \\
\text { Avaliaçào (dias) }\end{array}$} & \multicolumn{2}{|c|}{ Embalagem durante o armazenamento } & \multirow[t]{2}{*}{ Média } \\
\hline & Com & Sem & \\
\hline \multicolumn{4}{|c|}{--.- Taninos solúveis $\left(\mathrm{g} .100 \mathrm{~g}^{-1}\right)$} \\
\hline$\Xi$ & 0.11 & 0.06 & $0,08 \mathrm{a}$ \\
\hline 6 & 0.05 & 0.05 & $0.05 \mathrm{a}$ \\
\hline Média & $0.08 \mathrm{~A}$ & $0.06 \mathrm{~A}$ & - \\
\hline \multicolumn{4}{|c|}{ Firmeza $\left(\mathrm{kg} . \mathrm{cm}^{-2}\right)$} \\
\hline 3 & 3.28 & 2.59 & $2.92 \mathrm{a}$ \\
\hline 6 & 1.62 & 2.76 & $2,15 \mathrm{a}$ \\
\hline Mèdia & $2.38 \mathrm{~A}$ & $2.67 \mathrm{~A}$ & - \\
\hline \multicolumn{4}{|c|}{--- Perda de matéria fresca $(\%)$-.-- } \\
\hline 3 & 1.93 & 2.25 & $2.09 \mathrm{~b}$ \\
\hline 6 & 3.85 & 4.11 & $3.98 \mathrm{a}$ \\
\hline Média & $2.89 \mathrm{~B}$ & $3.18 \mathrm{~A}$ & - \\
\hline 3 & \multicolumn{2}{|c|}{ pH } & $5.78 \mathrm{~b}$ \\
\hline 6 & 6.12 & 6.03 & $6.07 \mathrm{a}$ \\
\hline Média & $5.94 \mathrm{~A}$ & $5.91 \mathrm{~A}$ & - \\
\hline 3 & 20.54 & 21.17 & $20.85 \mathrm{a}$ \\
\hline 6 & 21.38 & 21.01 & $21,15 \mathrm{a}$ \\
\hline Média & $20.91 \mathrm{~A}$ & $21.09 \mathrm{~A}$ & - \\
\hline \multicolumn{4}{|c|}{ _... ATT (\% ácido málico) -...... } \\
\hline 3 & 0,1064 & 0,0681 & $0,0864 \mathrm{a}$ \\
\hline 6 & 0.0708 & 0,0599 & $0,0652 \mathrm{a}$ \\
\hline Média & $0,0879 \mathrm{~A}$ & $0,0639 \mathrm{~A}$ & - \\
\hline \multicolumn{4}{|c|}{... Ácido ascórbico (mg.100 $\left.\mathrm{g}^{-1}\right) \ldots$} \\
\hline 3 & 34,55 & 31,72 & $33,14 \mathrm{~b}$ \\
\hline 6 & 42,49 & 39,53 & $41,01 \mathrm{a}$ \\
\hline Média & $38,52 \mathrm{~A}$ & $35,63 \mathrm{~A}$ & - \\
\hline
\end{tabular}

Para cada variável, as médias seguidas pela mesma letra minúscula na coluna e mesma letra maiúscula na linha nāo diferem significativamente entre si pelo teste de Tukey ao nível de $5 \%$ de probabilidade. (Análice inicial: tanino $=0,24$ e $0,45 \mathrm{~g} \cdot 100 \mathrm{~g}^{-1}$; firmeza $=9,21$ e $9,99 \mathrm{~kg} \cdot \mathrm{cm}^{-2} ; \mathrm{pH}=5,84$ e 5,$78 ; \mathrm{SST}=$ 18.27 e $20,4^{\circ}$ Brix, ATT $=0,1027$ e $0,1161 \%$ ácido málico; ácido ascórbico $=46,50$ e $43,89 \mathrm{mg} .100 \mathrm{~g}^{-1}$ para frutos armazenados com e sem embalagem, respectivamente). 


\section{Firmeza de polpa}

A utilização de embalagem de polietileno durante 30 dias de armazenamento -efrigerado não interferiu na firmeza da polpa dos frutos após o processo de remoção da adstringência (Tabela 4). Verifica-se, no entanto, que os valores de firmeza de polpa, :anto dos frutos armazenados embalados como daqueles armazenados sem embalagem, ioram bastante inferiores aos valores médios constatados imediatamente ao término do วeriodo de armazenamento $\left(9,21\right.$ e $9,99 \mathrm{~kg} . \mathrm{cm}^{-2}$, respectivamente). Moura (1995), de 亏̧ræa semelhante, observou que a utilização de embalagem, durante o armazenamento, zão apresentou efeito sobre a firmeza da polpa dos frutos quando submetidos, posieriomente, ao ratamento com ethephon.

Verificou-se, ao $3^{\circ}$ dia após o tratamento, uma redução acentuada na firmeza da zolpa (Tabela 4), o que tomou os frutos inaceitáveis ao consumo, uma vez que os frutos ¿este cultivar são consumidos com polpa firme.

\section{Perda de matéria fresca durante o tratamento}

Verifica-se na Figura 1 , que os frutos armazenados com embalagem apresentaram uma perda de matéria fresca estatisticamente superior aos frutos amzzzenados sem embalagem, o que pode ser explicado pela diferença no déficit de ?ressão de vapor (DPV) estabelecido nos dois ambientes de armazenamento.

O DPV corresponde à diferença entre a pressão de vapor dos espaços intercelulares do fruto e o ar circundante, de forma que quanto maior o déficit de pressão de vapor maior é a perda de matéria fresca pelo fruto (Chitarra \& Chitarra, 1990). A alta umidade relativa no interior da embalagem reduziu o DPV e, consequentemente, a perda de matéria fresca dos frutos durante o armazenamento (Pesis et al., 1986), no entanto, ao se retirar os frutos da embalagem a diferença entre a pressão de vapor dos espaços intercelulares do fruto e do ar circundante, menos saturado, tornou-se mais acentuada, condurindo à maior perda de matéria fresca através da transpiração. Os frutos armazenados sem embalagem não sofreram uma mudança abrupta de DPV, uma vez que 
a umidade relativa no interior da câmara de armazenamento estava próxima à umidade relativa da câmara de destanização.

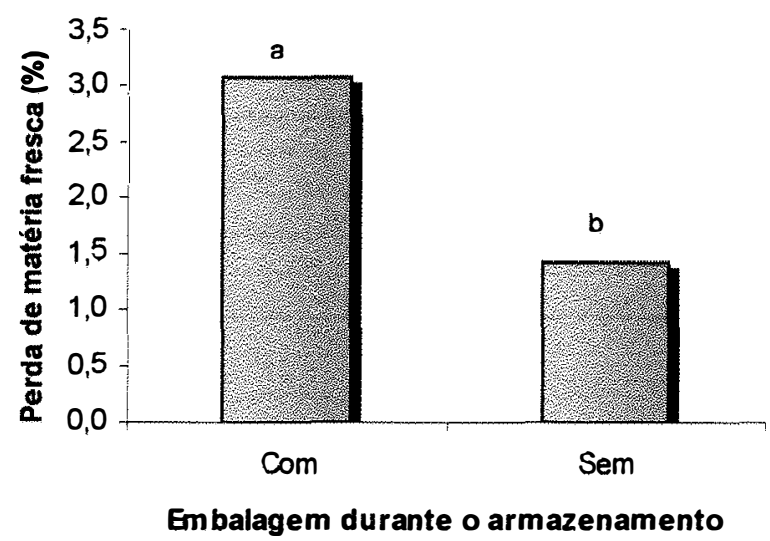

Figura 1 - Perda de matéria fresca de frutos de caquizeiro 'Giombo' durante o período de exposição ao vapor de álcool etílico. (As letras minúsculas indicam diferença significativa ao nível de $5 \%$ de probabilidade, pelo teste de Tukey). ESALQ, Piracicaba-SP, 1999.

\section{Perda de matéria fresca durante o período de avaliação}

Ao contrário do comportamento verificado durante o tratamento, a perda de matéria fresca durante o período de avaliação foi estatisticamente superior nos frutos armazenados sem embalagem (Tabela 4). Moura (1995), no entanto, afirmou que os frutos armazenados com ou sem embalagem perderam quantidades semelhantes de matéria fresca após a aplicação de ethephon.

Verificou-se um aumento na perda de matéria fresca em função do tempo, atingindo o valor médio de $3,98 \%$ ao final do $6^{\circ}$ dia de avaliação (Tabela 4).

Observou-se que os frutos apresentaram perda de matéria fresca acumulada, equivalente à perda durante o período de 30 dias de armazenamento e as perdas durante o tratamento e o período de avaliação; sendo que os frutos armazenados com embalagem apresentaram perda de matéria fresca equivalente a $6,03 \%(0,07 ; 3,07$ e $2,89 \%$, respectivamente), enquanto os frutos armazenados sem embalagem perderam $7,59 \%$ de 
matéria fresca $(2,98 ; 1,43$ e $3,18 \%$, respectivamente). Verificou-se, dessa forma, que a utilização de embalagem durante o armazenamento refrigerado proporciona menor perda de matéria fresca ao final do processo, embora os frutos armazenados com embalagem tenham apresentado maior perda de matéria fresca durante a destanização.

A possível redução na qualidade dos frutos decorrente da elevada perda de matéria fresca constatada ao $3^{\circ}$ dia de avaliação $(5,86 \%$, sendo $3,77 \%$ equivalente ao armazenamento e destanização), adicionada à firmeza insuficiente da polpa, tornou os frutos pouco aceitáveis comercialmente.

\section{Potencial hidrogeniônico $(\mathrm{pH})$}

$\mathrm{O}$ uso de embalagem de polietileno durante 30 dias de armazenamento não interferiu sobre o valor de $\mathrm{pH}$ da polpa dos frutos após o processo de destanização (Tabela 4). Verifica-se, no entanto, que houve um aumento no valor de $\mathrm{pH}$, tanto dos frutos armazenados embalados como daqueles armazenados sem embalagem quando comparado aos valores médios constatados ao término do período de armazenamento (5,84 e 5,78, respectivamente). Tais resultados estão de acordo com Moura (1995), que constatou que a utilização de embalagem durante o armazenamento não apresentou efeito sobre o valor de $\mathrm{pH}$ dos frutos submetidos posteriormente ao tratamento com ethephon.

Houve diferença significativa entre os períodos de 3 e 6 dias posteriores à exposição dos frutos ao vapor de álcool etílico, verificando-se ao $6^{\circ}$ dia de avaliação o valor de $\mathrm{pH}$ equivalente a 6,07 , estatisticamente superior ao valor verificado ao $3^{\circ}$ dia de avaliação $(5,78)$.

\section{Sólidos solúveis totais}

A utilização de embalagem durante o período de 30 dias de armazenamento não interferiu sobre o teor de sólidos solúveis da polpa dos frutos após o processo de 
remoção da adstringência (Tabela 4). Entretanto, houve um aumento no teor de sólidos solúveis, tanto dos frutos armazenados embalados como dos armazenados sem embalagem quando comparado aos valores médios constatados ao término do periodo de armazenamento (18,27 e $20,4^{\circ} \mathrm{Brix}$, respectivamente). Ao contrário dos resultados obtidos neste experimento, Moura (1995) verificou que a utilização de embalagem durante o armazenamento proporcionou maior teor de sólidos solúveis nos frutos armazenados sem embalagem, quando submetidos ao tratamento com ethephon.

Embora não tenha havido diferença significativa entre os períodos de 3 e 6 dias posteriores à exposição dos frutos ao vapor de álcool etílico, constatou-se um aumento no teor médio de sólidos solúveis após o tratamento (Tabela 4), decorrente, possivelmente, da perda de matéria fresca pelos frutos, bem como da hidrólise de alguns compostos, como substâncias pécticas e hemicelulose da parede celular, em conseqüência do avanço do amadurecimento (Wills et al., 1981).

\section{Acidez total titulável}

A utilização de embalagem de polietileno durante 30 dias de armazenamento refrigerado não interferiu sobre a acidez da polpa dos frutos após o processo de remoção da adstringência (Tabela 4). Verifica-se, no entanto, que houve uma diminuição na acidez, tanto dos frutos armazenados com embalagem como daqueles armazenados sem embalagem quando comparada aos valores médios constatados ao término do período de armazenamento $(0,1027$ e $0,1161 \%$ de ácido málico, respectivamente):

Moura (1995), de forma semelhante, relatou que a utilização de embalagem, durante o armazenamento, não apresentou efeito sobre a acidez titulável dos frutos submetidos, posteriormente, ao tratamento com ethephon como um método de indução ao amadurecimento.

Verifica-se que não houve diferença significativa entre os períodos de 3 e 6 dias posteriores à exposição dos frutos ao vapor de álcool etílico, verificando-se ao $6^{\circ}$ dia de avaliação o menor valor percentual de acidez $(0,0652)$, de forma a confirmar o 
comportamento do pH. De acordo com Chitarra \& Chitarra (1990), o teor de ácidos orgânicos, com poucas exceções, diminui com a maturação, em decorrência do processo respiratório ou de sua conversão em açúcares.

\section{Ácido ascórbico}

A análise da Tabela 4 indica que a utilização de embalagem durante 30 dias de armazenamento não interferiu sobre o teor de ácido ascórbico da polpa dos frutos após o processo de destanização. Houve, no entanto, uma redução no teor de vitamina $C$, tanto dos frutos armazenados embalados como daqueles armazenados sem embalagem, quando comparado aos valores médios constatados ao término do armazenamento (46,50 e $43,89 \mathrm{mg} 100 \mathrm{~g}^{-1}$, respectivamente). Tal redução é decorrente do grau de maturação dos frutos (Montenegro \& Salibe, 1959), independente, neste caso, da condução do armazenamento, uma vez que a utilização ou não de embalagem proporcionou grau de maturação semelhante durante a destanização dos frutos.

Houve diferença significativa entre os periodos de 3 e 6 dias posteriores à exposição dos frutos ao vapor de álcool etílico, constatando-se, ao $3^{\circ}$ dia de avaliação, o menor teor de vitamina $\mathrm{C}\left(33,14 \mathrm{mg} .100 \mathrm{~g}^{-1}\right)$, inferior àquele constatado ao $6^{\circ}$ dia de avaliação (Tabela 4).

A exposição dos frutos ao vapor de álcool etílico, como um processo de antecipação da maturação, promove uma antecipação da ascensão climatérica, envolvendo um aumento na taxa respiratória (Itamura et al., 1997). Conforme relataram Chitarra \& Chitarra (1990), a respiração resulta em modificações dos constituintes do fruto, dentre os quais encontram-se as vitaminas. 
Remoção da adstringência após 60 dias de armazenamento refrigerado

$\mathrm{Na}$ Tabela 5 encontra-se resumida a análise da variância dos efeitos dos tratamentos sobre a perda de matéria fresca analisada no experimento. Nota-se que houve efeito da utilização de embalagem durante o armazenamento sobre a variável analisada, indicando que a perda de matéria fresca, tanto durante o tratamento como durante o período de avaliação, é influenciada pelo ambiente saturado que se desenvolve no interior da embalagem de polietileno durante o armazenamento refrigerado.

Tabela 5 - Análise de variância dos efeitos da utilização de embalagem durante 0 armazenamento refrigerado e do período de avaliação sobre a perda de matéria fresca em frutos de caquizeiro 'Giombo'. ESALQ, PiracicabaSP, 1999.

\begin{tabular}{llc}
\hline & \multicolumn{2}{c}{ Variáveis analisadas $^{\mathrm{x}}$} \\
\cline { 2 - 3 } $\begin{array}{c}\text { Efeitos principais } \\
\text { e interação }\end{array}$ & $\mathrm{PMF}^{1}$ & PMF $^{2}$ \\
\hline
\end{tabular}

--o----Significância do teste F

Embalagem durante

armazenamento (E)

Periodo de

avaliação (PA)

E $\times$ PA

-

n.s.

\begin{tabular}{lr}
\hline C.V. $(\%)$ & 13,99 \\
\hline
\end{tabular}

${ }^{x} \mathrm{PMF}^{1}=$ perda de matéria fresca durante o tratamento; $\mathrm{PMF}^{2}=$ perda de matéria fresca durante o periodo de avaliação.

n.s.; **; * = não significativo; significativo ao nivel de 1 e $5 \%$ de probabilidade, respectivamente. 
Os valores das demais variáveis correspondem às médias das repetições avaliadas 3 dias após o tratamento (Tabela 6 ). A avaliação ao $6^{\circ}$ dia após o tratamento foi suspensa em função da podridão generalizada que se estabeleceu nos frutos, causada por Phomopsis sp., o que impossibilitou a análise estatística dos dados.

Tabela 6 - Efeito da embalagem de polietileno durante 60 dias de armazenamento refrigerado sobre as características fisicas e químicas de frutos de caquizeiro 'Giombo' no processo de remoção da adstringência. ESALQ, Piracicaba-SP, 1999.

\begin{tabular}{|c|c|c|c|c|c|}
\hline \multirow{3}{*}{ Caracteristicas } & \multicolumn{4}{|c|}{ Embalagem durante o armazenamento } & \multirow{3}{*}{ Médias $^{2}$} \\
\hline & \multicolumn{2}{|c|}{ Com } & \multicolumn{2}{|c|}{ Sem } & \\
\hline & $\begin{array}{l}\text { Análise } \\
\text { Inicial }^{1}\end{array}$ & $\begin{array}{l}\text { Análise } \\
\text { ao } 3^{\circ} \text { dia }\end{array}$ & $\begin{array}{l}\text { Análise } \\
\text { Inicial }^{1}\end{array}$ & $\begin{array}{l}\text { Análise } \\
\text { ao } 3^{\circ} \text { dia }\end{array}$ & \\
\hline Taninos solúveis $(\mathrm{g} / 100 \mathrm{~g})$ & 0,23 & 0,12 & 0,30 & 0,10 & 0,11 \\
\hline Firmeza da polpa $\left(\mathrm{kg} \cdot \mathrm{cm}^{-2}\right)$ & 4,37 & 1,20 & 5,97 & 1,04 & 1,12 \\
\hline $\mathrm{pH}$ & 6,03 & 6,13 & 6,08 & 6,25 & 6,19 \\
\hline Solidos Solúveis Totais ( ${ }^{\circ}$ Brix) & 18,37 & 19,83 & 18,31 & 18,56 & 19,19 \\
\hline Acidez Total Titulável (\% ác.málico) & 0,0782 & 0,0748 & 0,0815 & 0,0692 & 0,0720 \\
\hline Ácido ascórbico (mg/100g) & 47,49 & 52,03 & 41,41 & 51,33 & 51,70 \\
\hline
\end{tabular}

'Análise inicial realizada imediatamente após o armazenamento;

= Valores médios obtidos 3 dias após o tratamento.

\section{Taninos solúveis}

Verifica-se na Tabela 6, que embora o teor de taninos solúveis dos frutos armazenados sem embalagem, verificado ao término do armazenamento, tenha sido superior ao daqueles armazenados com embalagem, os frutos provenientes de ambos os tratamentos atingiram teores muito próximos durante a destanização, comportamento semelhante àquele constatado quando procedeu-se à remoção da adstringência dos frutos armazenados durante 30 dias. 
Semelhantemente aos resultados obtidos no processo de destanização após o primeiro período de armazenamento, constatou-se que os frutos tiveram sua adstringência reduzida a niveis não detectáveis ao paladar 3 dias após o tratamento, quando verificou-se o teor médio de $0,11 \mathrm{~g}$ de taninos solúveis por $100 \mathrm{~g}$ de polpa (Tabela 6).

\section{Firmeza de polpa}

Nota-se na Tabela 6, que os frutos armazenados com embalagem apresentaramse amolecidos ao final do armazenamento, com firmeza de polpa de $4,37 \mathrm{~kg} . \mathrm{cm}^{-2}$, enquanto os frutos armazenados sem embalagem apresentaram maior firmeza de polpa $\left(5,97 \mathrm{~kg} . \mathrm{cm}^{-2}\right)$, decorrente do murchamento. Estes resultados estão de acordo com os obtidos por Brackmann \& Saquet (1995), que verificaram maior resistência à penetração da ponteira do penetrômetro em frutos mais desidratados

A aparência dos frutos constatada ao final do periodo de 60 dias de armazenamento refrigerado, associada à baixa firmeza da polpa inviabilizaria o procedimento de remoção da adstringência dos frutos visando a comercialização; no entanto, procedeu-se à destanização com o objetivo de avaliar o comportamento das variáveis analisadas.

Verificou-se, ao $3^{\circ}$ dia após o tratamento, uma redução acentuada na firmeza da polpa, atingindo o valor médio de $1,12 \mathrm{~kg} . \mathrm{cm}^{-2}$, o que caracterizou frutos extremamente amolecidos (Tabela 6).

\section{Perda de matéria fresca durante o tratamento}

Verificou-se ao término do armazenamento, que os frutos armazenados sem embalagem apresentaram enrugamento da epiderme e murchamento, decorrente da perda de matéria fresca através da transpiração, o que não foi verificado nos frutos embalados, que apresentaram polpa bastante amolecida. 
Ao término do tratamento para remoção da adstringência, os frutos armazenados sem embalagem apresentaram-se bastante amolecidos, não se verificando o enrugamento da epiderme característico dos frutos ao final do armazenamento; no entanto, constataram-se grandes rachaduras na polpa de alguns frutos. Notou-se amolecimento semelhante na polpa dos frutos armazenados com embalagem, onde as rachaduras foram menos evidentes, restringindo-se somente à epiderme dos mesmos.

Percebe-se, através da Figura 2, que os frutos armazenados embalados apresentaram perda de matéria fresca estatisticamente superior aos frutos armazenados sem embalagem, o que pode ser explicado pelo déficit de pressão de vapor (DPV) estabelecido nos dois ambientes de armazenamento. Tal comportamento foi observado, de forma semelhante, quando procedeu-se à remoção da adstringência dos frutos submetidos ao período de 30 dias de armazenamento.

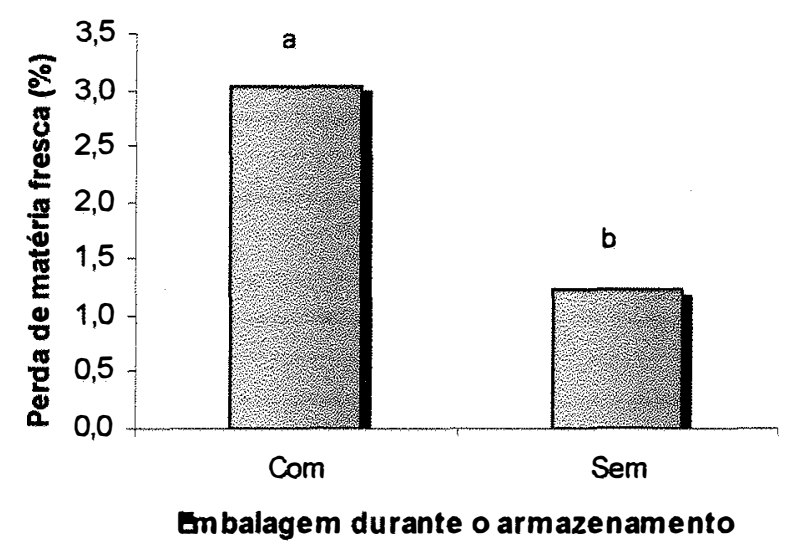

Figura 2 - Perda de matéria fresca de frutos de caquizeiro 'Giombo' durante o período de exposição ao vapor de álcool etílico. (As letras minúsculas indicam diferença significativa ao nível de $5 \%$ de probabilidade, pelo teste de Tukey). ESALQ, Piracicaba-SP, 1999.

\section{Perda de matéria fresca durante o período de avaliação}

Conforme verificado anteriormente, no processo de remoção da adstringência dos frutos armazenados durante 30 dias, a análise dos dados apresentados na Tabela 7 
indica que a perda de matéria fresca durante o periodo de avaliação foi estatisticamente superior nos frutos armazenados sem embalagem. Verificou-se um aumento na perda de matéria fresca em função do tempo, atingindo o valor médio de $5,98 \%$ ao final do $6^{\circ}$ dia de avaliação.

A perda de matéria fresca acumulada, equivalente à perda durante o periodo de 60 dias de armazenamento e as perdas durante o tratamento e o periodo de avaliação, foi superior nos frutos armazenados sem embalagem, que perderam 11,51\% de matéria fresca $(5,56 ; 1,23$ e $4,72 \%$, respectivamente), enquanto a perda de matéria fresca dos futos armazenados com embalagem foi equivalente a 7,52\% (0,16;3,04 e 4,32\%, respectivamente). Os resultados confirmam que a utilização de embalagem, durante o armazenamento refrigerado, proporciona menor perda de matéria fresca ao final do processo.

Tabela 7 - Efeito da embalagem de polietileno durante o armazenamento e do período de avaliação após a remoção da adstringência sobre a perda de matéria fresca (\%) de frutos de caquizeiro 'Giombo' armazenados por 60 dias a $1^{\circ} \mathrm{C}$ e 95-98\% UR. ESALQ, Piracicaba-SP, 1999.

\begin{tabular}{cccc}
\hline Periodo de & \multicolumn{2}{c}{ Embalagem durante o armazenamento } & Média \\
\cline { 2 - 3 } Avaliação (dias) & \multicolumn{1}{c}{ Com } & \multicolumn{1}{c}{ Sem } & \\
\hline & \multicolumn{2}{c}{ Perda de matéria fresca $(\%)$} & \\
3 & 2,83 & 3,28 & $3,05 \mathrm{~b}$ \\
6 & 5,81 & 6,16 & $5,98 \cdot \mathrm{a}$ \\
Média & $4,32 \mathrm{~B}$ & $4,72 \mathrm{~A}$ & - \\
\hline
\end{tabular}

Médias seguidas pela mesma letra minúscula na coluna e mesma letra maiúscula na linha não diferem significativamente entre si pelo teste de Tukey ao nivel de $5 \%$ de probabilidade.

\section{Potencial hidrogeniônico (pH)}

Verifica-se que houve um aumento no valor de $\mathrm{pH}$, tanto dos frutos armazenados embalados como daqueles armazenados sem embalagem, quando 
comparado aos valores médios constatados ao término do periodo de armazenamento (Tabela 6). Tal comportamento foi observado, de forma semelhante, quando procedeu-se à remoção da adstringência dos frutos armazenados durante 30 dias.

\section{Sólidos solúveis totais}

Percebe-se que houve um aumento no teor de sólidos solúveis nos frutos provenientes de ambos os tratamentos quando comparado aos valores médios constatados ao término do período de armazenamento (Tabela 6). Tais resultados foram semelhantemente observados quando procedeu-se à remoção da adstringência dos frutos submetidos ao período de 30 dias de armazenamento.

\section{Acidez total titulável}

Nota-se que houve uma diminuição na acidez, tanto dos frutos armazenados embalados como daqueles armazenados sem embalagem, quando comparada aos valores médios constatados ao término do periodo de armazenamento, de forma a confirmar o comportamento do $\mathrm{pH}$ (Tabela 6). A redução da acidez titulável foi, de forma semelhante, constatada no processo de remoção da adstringência dos frutos armazenados durante 30 dias.

\section{Ácido ascórbico}

Verifica-se na Tabela 6 , que houve um aumento no teor de vitamina $C$ nos frutos provenientes de ambos os tratamentos, quando comparado aos valores médios constatados ao término do armazenamento. Tais resultados foram contrários aos esperados, uma vez que os frutos provenientes do processo de destanização que se seguiu ao periodo de 30 dias de armazenamento apresentaram um decréscimo no teor de vitamina C, o que segundo Montenegro \& Salibe (1959), é decorrente do grau de 
maturação, apresentando, os frutos verdolengos, maior conteúdo em vitamina $C$ que os frutos maduros ou senescentes.

\section{Remoção da adstringência após 90 dias de armazenamento refrigerado}

Constatou-se ao término do armazenamento, que os frutos armazenados sem embalagem apresentaram-se excessivamente murchos e com intenso enrugamento da epiderme, decorrente da perda de matéria fresca através da transpiração. Os frutos armazenados com embalagem apresentaram-se ainda túrgidos, porém com polpa bastante amolecida, de forma que a qualidade dos frutos provenientes de ambos os tratamentos foi insuficiente para comercialização.

Ao término do tratamento para remoção da adstringência os frutos armazenados sem embalagem apresentaram-se bastante amolecidos, não se verificando o enrugamento da epiderme característico dos frutos ao final do armazenamento; no entanto, constataram-se grandes rachaduras na polpa de alguns frutos. Notou-se amolecimento semelhante na polpa dos frutos armazenados com embalagem, onde as rachaduras ocorreram em $100 \%$ dos frutos, impossibilitando as avaliações de suas características quimicas e fisicas.

\section{CONCLUSÕES}

- A utilização de embalagem de polietileno durante o armazenamento refrigerado de caquis 'Giombo' não apresenta eficiência na completa destanização dos frutos, havendo a necessidade de tratamento adicional para remoção total da adstringência;

- O armazenamento refrigerado dos frutos pode ser realizado até 30 dias sob temperatura de $1{ }^{\circ} \mathrm{C}$ e $95-98 \%$ UR, no entanto os frutos apresentam baixa firmeza de polpa e elevada perda de matéria fresca após o processo de destanização; 
- Não se recomenda o armazenamento refrigerado por um período igual ou superior a 60 dias, uma vez que os frutos apresentam aparência pouco atrativa e baixa firmeza de polpa.

\section{REFERÊTCLAS BIBLIOGRÁFICAS}

AWAD. M; AMENOMORI, H. Efeito do ácido 2-cloroetilfosfônico e do confinamento em sacos de polietileno na destanização do caqui 'Taubaté' (Diospyros Kaki). In: CONGRESSO BRASILEIRO DE FRUTICULTURA, Campinas, SP, Brasil, 1971. Anais. v. 1, p.257-261.

BIASI L.A.; GERHARDT, I.R. Efeito da aplicação de vinagre, álcool e ethephon na des:anização de caquis cv. Okira. Revista Brasileira de Fruticultura, v.14, n.2, p. $31-36,1992$.

BRACKMANN, A.; SAQUET, A.A. Efeito da temperatura e condições de atmosfera comrolada sobre a conservação de caqui (Diospyros kaki L.). Ciência Rural, v.5, n. ... p. $375-378,1995$.

CARVILHO, C.R.L.; MANTOVANI, D.M.B.; CARVALHO, P.R.N.; MORAES, R.M1.M. Análises químicas de alimentos. Campinas: ITAL, 1990. 121p. (Manual Técnico).

CHITARRA, M.I.F.; CHITARRA, A.B. Pós-colheita de frutos e hortaliças: fisiologia e manuseio. Lavras: ESAL/FAEPE, 1990. 293p.

FUKUSHIMA, T.; KITAMURA, T.; MURAYAMA, H.; YOSHIDA, T. Mechanisms of astringency removal by ethanol treatment in 'Hiratanenashi' kaki fruits. Journal of the Japanese Society for Horticultural Science, v.60, n.3, p.685-694, 1991. Resumo em CAB Abstracts on CD-ROM, 1993-1994. 
HONG, Y.P.; LEE, J.S.; KM, Y.B. Studies on the techniques of astringent persimmon (Diospyros kaki L.) storage and deastringency in polyethylene film bags. RDAJournal of Agricultural Science, v.35, n.2, p.755-760, 1993. Resumo em CAB Abstracts on CD-ROM, 1993-1994.

ITAMLRA, H.; OHHO, Y; YAMAMURA, H. Characteristics of fruit softening in Japanese persimmon 'Saijo' Acta Horticulturae, n.436, p. 179-188, 1997.

ITO, S. The persimmon. In: HULME, A.C. The biochemistry of fruits and their products. London: Academic Press, 1971, v.2, cap. 8, p.281- 301.

KATO, K. Conditions for tanning and sugar extraction, the relationship of tannin concentration to astringency and the behaviour of ethanol during the removal of astringency by ethanol in persimmon fruits. Journal of the Japanese Society for Horticultural Science, v.53, n.2, p.127-134, 1984. Resumo em CAB Abstracts on CD-ROM, 1984-1986.

KATO, K. Astringency removal and ripening as related to temperature during the astringency removal by ethanol in persimmon fruits. Journal of the Japanese Society for Horticultural Science, v.55, n.4, p.498-509, 1987. Resumo em CAB Abstracts on CD-ROM, 1987-1989.

LEE, E.J;; YANG, Y.J. Postharvest physiology and storage disorders affected by temperature and PE film thickness in 'Fuyu' persimmon fruit. Journal of the Korean Society for Horticultural Science, v.38, n.5, p.516-519, 1997. Resumo em CAB Abstracts on CD-ROM, 1996-1998.

LYON, B.G.; SENTER, S.D.; PAYNE, J.A. Quality characteristics of oriental persimmons (Diospyros kaki L. cv. Fuyu) grown in the southeastern United States. Journal of Food Science, v.57, n.3, p.693-695, 1992. 
MARTINS, F.P.; PEREIRA, F.M. Cultura do caquizeiro. Jaboticabal: FUNEP, 1989. $71 \mathrm{p}$.

MONTENEGRO, H.W.S.; SALIBE, A.A. Vitamina C em caqui (Diospyros kaki L.) Revista de Agricultura, v.34, n.3, p. 183-195, 1959.

MOURA, M.A. da. Efeito da embalagem e do armazenamento no amadurecimento do caqui (Diospyros kaki L.) cultivar Taubaté. Viçosa, 1995. 84p. Dissertação (M.S.) - Universidade Federal de Viçosa.

MOURA, M.A.; LOPES, L.C.; CARDOSO, A.A.; MIRANDA, L.C.G. Efeito da embalagem e do armazenamento no amadurecimento do caqui. Pesquisa Agropecuária Brasileira, v.32, n.11, p.1105-1109, 1997.

PEKMEZCI, M.; ERKAN, M.; GÜBBÜK, H. The effects of harvest time, and method and duration of storage on quality of 'Hachiya' e 'Fuyu' persimmons. Acta Horticulturae, n.441, p. 279-286, 1997.

PENTEADO, S.R. Cultura do caquizeiro. In: Fruticultura de clima temperado em São Paulo. Campinas: Fundação Cargill, 1986. cap. 8, p.157-173.

PESIS, E.; LEVI, A.; BEN-ARIE, R. Deastringency of persimmon fruits by creating a modified atmosphere in polyethylene bags. Journal of Food Science, v.51, n.4, p.1014-1016, 1041, 1986.

SUGIURA, A; TOMANA, T. Relationships of ethanol production by seeds of different types of Japanese persimmons and their tannin content. HortScience, v.18, n.3, p.319-321, 1983.

TURK, R. The cold storage of persimmons (Diospyros kaki cv. Fuyu) harvested at different maturities and the effect of different $\mathrm{CO}_{2}$ applications on fruit ripening. Acta Horticulturae, n.343, p.190-194, 1993. 
VIDRIH, R.; SIMCIC, M; HRIBAR, J.; PLESTENJAK, A. Astringency removal by high $\mathrm{CO}_{2}$ treatment in persimmon fruit (Diospyros kaki). Acta Horticulturae, n. 368, p.652-656, 1994.

WILLS, R.H.H.; LEE, T.H.; GRAHAM, D.; McGLASSON, W.B.; HALL, E.G. Postharvest - an introduction to the physiology and handling of fruit and vegetables. Kensington: New South Wales University Press, 1981. 161p. 


\section{5 - CONSIDERAÇÕES GERAIS}

A exposição de frutos de caquizeiro 'Giombo' ao vapor de álcool etílico comprovou ser um método prático e eficiente no processo de remoção da adstringência.

O experimento cujo objetivo foi estudar o efeito do período de exposição de frutos de caquizeiro ao vapor de álcool etílico indicou que os periodos de 24 e 36 horas foram igualmente eficientes no processo de remoção da adstringência dos frutos, de forma que tal processo pode ser realizado no periodo de 24 horas.

O teor de taninos solúveis sofreu um decréscimo a partir do $2^{\circ}$ dia após o término do tratamento, atingindo, ao $4^{\circ}$ dia, teores próximos a $0,1 \%$, indicando a perda da adstringência dos frutos, o que foi confirmado através de avaliações degustativas.

O inicio do amolecimento da polpa dos frutos foi constatado após o periodo de 48 horas do tratamento, sendo que a redução na firmeza da polpa prolongou-se linearmente durante o periodo avaliado.

Os frutos submetidos ao tratamento de 48 horas apresentaram maior perda de matéria fresca durante o período de exposição ao vapor de etanol. O periodo de avaliação foi marcado por um aumento linear na perda de matéria fresca, atingindo o valor de $5,34 \%$ ao final de 10 dias.

A perda de ácido ascórbico, decorrente do grau de maturação dos frutos, foi equivalente a $37,4 \%$, desde o início do tratamento ao término do período de 10 dias.

O melhor período para consumo dos frutos situou-se entre o $4^{\circ}$ e o $8^{\circ}$ dia após o tratamento, considerando-se que a partir do $4^{\circ}$ dia a concentração de taninos solúveis 
ficou abaixo de $0,1 \%$ e a firmeza da polpa dos frutos se manteve aceitável durante o periodo de oito dias posteriores ao tratamento.

O experimento que teve por finalidade o estudo do efeito da utilização de embalagem de polietileno no acondicionamento dos frutos de caquizeiro 'Giombo', durante $o$ armazenamento refrigerado, indicou que os frutos mantiveram elevada qualidade durante os primeiros 30 dias de armazenamento; sendo que ao término dos períodos de 60 e 90 dias a qualidade comercial dos frutos foi prejudicada em função da aparência pouco atrativa, decorrente do murchamento do fruto e enrugamento da epiderme, associada à firmeza insuficiente da polpa, de forma que não se recomenda o armazenamento refrigerado por um periodo igual ou superior a 60 dias.

A utilização de embalagem de polietileno comprovou ser eficiente no estabelecimento de ambiente favorável à polimerização dos taninos, com conseqüente redução da adstringência, embora a espessura de $0,06 \mathrm{~mm}$ não tenha sido eficiente em remover completamente a adstringência dos frutos, que apresentaram teor médio de $0,24 \%$ de taninos solúveis durante os 90 dias de armazenamento refrigerado, o que caracterizou frutos ligeiramente adstringentes; de forma a necessitarem de um tratamento para remoção da adstringência, posterior ao armazenamento, a fim de tornálos comestiveis. Ao término do período de 30 dias de armazenamento os frutos embalados haviam perdido $54,7 \%$ do teor de taninos solúveis verificado anteriormente ao armazenamento, sendo que ao final dos demais períodos o teor de taninos solúveis permaneceu inalterado.

Frutos armazenados por 30 dias e submetidos ao vapor de álcool etílico tornaram-se não adstringentes após três dias do tratamento, no entanto, a firmeza insuficiente da polpa associada à elevada perda de matéria fresca tomou os frutos pouco aceitáveis comercialmente.

Os frutos acondicionados em embalagem de polietileno durante 30 e 60 dias de armazenamento refrigerado apresentaram perda de matéria fresca superior aos frutos armazenados sem embalagem quando expostos ao vapor de etanol; no entanto, a perda de matéria fresca acumulada, referente aos períodos de armazenamento, tratamento para 
remoção da adstringência e avaliação foi superior nos frutos armazenados sem embalagem, indicando que o uso de sacos de polietileno durante o armazenamento refrigerado proporcionou menor perda de matéria fresca ao final do processo.

Os frutos armazenados durante 60 dias e submetidos, posteriormente, ao processo de destanização, apresentaram-se amolecidos, sendo que alguns deles apresentaram rachaduras, que restringiram-se à epiderme nos frutos armazenados com embalagem e atingiram a polpa naqueles armazenados sem embalagem. Os mesmos sintomas foram verificados nos frutos armazenados durante 90 dias, onde as rachaduras ocorreram em $100 \%$ dos frutos armazenados embalados.

Houve estabelecimento de podridão generalizada causada por Phomopsis sp. ao $6^{\circ}$ dia de avaliação dos frutos armazenados durante o período de 60 dias e submetidos, posteriormente, ao processo de remoção da adstringência.

Para o cultivar Giombo, que necessita de um processo adicional para remoção da adstringência após o armazenamento refrigerado, não se recomenda tal procedimento, em condições idênticas, uma vez que mesmo apresentando elevada qualidade ao término do período de 30 dias de armazenamento, os frutos sofreram grande perda da qualidade comercial após a destanização, o que os tornou inaceitáveis ao consumo. 


\section{REFERÊNCIAS BIBLIOGRÁFICAS}

ANUÁRIO DA AGRICULTURA BRASILEIRA FNP Consultoria \& Comércio. M\&S Mendes \& Scotoni: Argos Comunicação, 1999. 521 p.

AWAD, M. Fisiologia pós-colheita de frutos. São Paulo: Nobel, 1993. 117p

AWAD, M.; AMENOMORI, H. Efeito do ácido 2-cloroetilfosfônico e do confinamento em sacos de polietileno na destanização do caqui 'Taubaté' (Diospyros Kaki). In: CONGRESSO BRASIEIRO DE FRUTICULTURA, Campinas, SP, Brasil, 1971. Anais. v. 1, p.257-261.

AWAD, M.; CASTRO, P.R.C. Introdução à fisiologia vegetal. São Paulo: Nobel, 1992. 180p.

BEN-AIRE, R.; ZUTKHI, Y. Extending the storage life of 'Fuyu' persimmon by modified-atmosphere packaging. HortScience, v.27, n.7, p.811-813, 1992.

BENDER, RJ. Colheita e armazenagem. In: Manual da cultura da macieira. Florianópolis: EMPASC, 1986. cap.21, p.521-550.

BIASI, L.A.; GERHARDT, I.R. Efeito da aplicação de vinagre, álcool e ethephon na destanização de caquis cv. Okira. Revista Brasileira de Fruticultura, v.14, n.2, p.31-36, 1992. 
BRACKMANN, A.; SAQUET, A.A. Efeito da temperatura e condições de atmosfera controlada sobre a conservação de caqui (Diospyros kaki L.). Ciência Rural, v.5, n.3, p.375-378, 1995.

CAMPO-DALL'ORTO, F.A.; OJMMA, M.; BARBOSA, W.; ZULLO, M.A.T. Novo processo de avaliação da adstringência dos frutos no melhoramento do caquizeiro. Bragantia, v.55, n.2, p.237-243, 1996.

CHITARRA, M.I.F.; CHITARRA, A.B. Pós-colheita de frutos e hortaliças: fisiologia e manuseio. Lavras: ESAL/FAEPE, 1990. 293p.

COSTA, A. N. da. Produção e qualidade dos frutos de diferentes variedades de caqui (Diospyros kaki L.), visando à industrialização. Viçosa, 1984. 50p. Dissertação (M.S.) - Universidade Federal de Viçosa.

ESGUERRA, E.B.; KAWADA, K.; KITAGAWA, H.; SUBHADRABANDHU, S. Removal of astringency in 'Amas' banana (Musa AA group) with postharvest ethanol treatment. Acta Horticulturae, n.321, p.811-820, 1992.

FELIPPE, G.M. Etileno. In: FERRI, M.G. Fisiologia Vegetal. São Paulo: EPU, 1986. v.2, cap.6, p.163-192.

FUKUSHIMA, T.; KITAMURA, T.; MURAYAMA, H.; YOSHIDA, T. Mechanisms of astringency removal by ethanol treatment in 'Hiratanenashi' kaki fruits. Journal of the Japanese Society for Horticultural Science, v.60, n.3, p.685-694, 1991. Resumo em CAB Abstracts on CD-ROM, 1993-1994.

GRIERSON, W.; WARDOWSKI, W.F. Relative humidity effects on the postharvest life of fruits and vegetables. HortScience, v.13, n.5, p.22-26, 1978. 
HARVEY, J.M.; SMITH Jr.,W.L.; KAUFMAN, J. Market diseases of stone fruits: cherries, peaches, nectarines, apricots and plums, Washington, 1972. 75p.

HONG, Y.P.; LEE, J.S.; KIM, Y.B. Studies on the techniques of astringent persimmon (Diospyros kaki L.) storage and deastringency in polyethylene film bags. RDAJournal of Agricultural Science, v.35, n.2, p.755-760, 1993. Resumo em CAB Abstracts on CD-ROM, 1993-1994.

ITAMURA, H.; KITAMURA, T.: TAIRA, S.; HARADA, H.; ITO, N.; TAKAHASHI, Y.; FUKUSHIMA, T. Relationship between fruit softening, ethylene production and respiration in Japanese persimmon 'Hiratanenashi'. Journal of the Japanese Society for Horticultural Science, v.60, n.3, p.695-701, 1991. Resumo em CAB Abstracts on CD-ROM, 1993-1994.

ITAMURA, H.; OHHO, Y.; YAMAMURA, H. Characteristics of fruit softening in Japanese persimmon 'Saijo' Acta Horticulturae, n.436, p.179-188, 1997.

ITO, S. The persimmon. In: HULME, A.C. The biochemistry of fruits and their products. London: Academic Press, 1971. v.2, cap. 8, p.281- 301.

KADER, A.A. Postharvest technology of horticultural crops. Davis: University California, 1985. 192p.

KATO, K. Conditions for tanning and sugar extraction, the relationship of tannin concentration to astringency and the behaviour of ethanol during the removal of astringency by ethanol in persimmon fruits. Journal of the Japanese Society for Horticultural Science, v.53, n.2, p.127-134, 1984a. Resumo em CAB Abstracts on CD-ROM, 1984-1986. 
KATO, K. Astringency removal and ripening as related to ethanol concentration in persimmon fruits. Journal of the Japanese Society for Horticultural Science, v.53, n.3, p.278-289, 1984b. Resumo em CAB Abstracts on CD-ROM, 19871989.

$\mathrm{KATO}, \mathrm{K}$. Astringency removal and ripening as related to temperature during the astringency removal by ethanol in persimmon fruits. Journal of the Japanese Society for Horticultural Science, v.55, n.4, p.498-509, 1987. Resumo em CAB Abstracts on CD-ROM, 1987-1989.

LEE, E.J.; YANG, Y.J. Postharvest physiology and storage disorders affected by temperature and PE film thickness in 'Fuyu' persimmon fruit. Journal of the Korean Society for Horticultural Science, v.38, n.5, p.516-519, 1997. Resumo em CAB Abstracts on CD-ROM, 1996-1998.

LI, L.P.; HAN, T.; LIU, J.Y.; GUO, D.M. Changes of quality, related enzyme activity and astringency in individually package, air-evacuated persimmons during cold storage. Transactions of the Chinese Society of Agricultural Engineering, v. 14, n. 1, p.233-237, 1998. Resumo em CAB Abstracts on CD-ROM, 1996-1998.

LYON, B.G.; SENTER, S.D.; PAYNE, J.A. Quality characteristics of oriental persimmons (Diospyros kaki L. cv. Fuyu) grown in the southeastern United States. Journal of Food Science, v.57, n.3, p.693-695, 1992.

MARTINS, F.P.; PEREIRA, F.M. Cultura do caquizeiro. Jaboticabal: FUNEP, 1989. $71 \mathrm{p}$.

MOURA, M.A.; LOPES, L.C.; CARDOSO, A.A.; MIRANDA, L.C.G. Efeito da embalagem e do armazenamento no amadurecimento do caqui. Pesquisa Agropecuária Brasileira, v.32, n.11, p.1105-1109, 1997. 
PEKMEZCI, M; ERKAN, M.; GÜBBÜK, H. The effects of harvest time, and method and duration of storage on quality of 'Hachiya' e 'Fuyu' persimmons. Acta Horticulturae, n.441, p.279-286, 1997.

PENTEADO, S.R. Cultura do caquizeiro. In: Fruticultura de clima temperado em São Paulo. Campinas: Fundação Cargill, 1986. cap.8, p.157-173.

PESIS, E.; LEVI, A.; BEN-ARIE, R. Deastringency of persimmon fruits by creating a modified atmosphere in polyethylene bags. Journal of Food Science, v.51, n.4, p.1014-1016, 1041, 1986.

RAGAZZINI, D. El kaki. Madrid: Ediciones Mundi-Prensa, 1985. 176p.

SALUNKHE, D.K.; DESAI, B.B. Persimmon. In: Postharvest biotechnology of fruits. Boca Raton, Florida: CRC Press, Inc., 1984. v.II, cap.15, p.105-109.

SIMÃO, S. Tratado de fruticultura. Piracicaba: FEALQ, 1998. 760p.

SUGIURA, A.; TOMANA, T. Relationships of ethanol production by seeds of different types of Japanese persimmons and their tannin content. HortScience, v.18, n.3, p.319-321, 1983 .

SUGIURA, A.; YONEMORI, K.; HARADA, H.; TOMANA, T. Changes in the ethanol and acetaldehyde contents of Japanese persimmon fruits in relation to natural loss of astringency. Studies from the Institute of Horticulture, Kyoto University, v.9, p.41-47, 1979. Resumo em CAB Abstracts on CD-ROM, 1979-1981. 
TAIRA, S.; KUBO,Y; SUGIURA, A.; TOMANA, T. Comparative studies of postharvest fruit quality and storage quality in Japanese persimmon (Diospyros kaki L. cv. Hiratanenashi) in relation to different methods for removal of astringency. Journal of the Japanese Society for Horticultural Science, v.56, n.2, p.215-221, 1987. Resumo em CAB Abstracts on CD-ROM, 1987-1989.

TAIRA, S.; ITAMURA, H.; ABE, K.; OOI, K.; WATANABE, S. Effect of harvest maturity on removal of astringency in Japanese persimmon (Diospyros kaki Thunb.), 'Hiratanenashi' fruits. Journal of the Japanese Society for Horticultural Science, v.58, n.4, p. 813-818, 1990. Resumo em CAB Abstracts on CD-ROM, 1990-1991.

TAIRA, S.; SATOH, I.; WATANABE, S. Removal of the astringent taste from persimmons and softening following treatment. Agriculture and Horticulture, v.66, n. 12, p. 1401-1404, 1991. Resumo em CAB Abstracts on CD-ROM, 1995.

TAIRA, S.; SATOH, I.; WATANABE, S. Relationship between differences in the ease of removal of astringency among fruits of Japanese persimmon (Diospyros kaki Thunb.) and their ability to acumulate ethanol and acetaldehyde. Journal of the Japanese Society for Horticultural Science, v.60, n.4, p.1003-1009, 1992. Resumo em CAB Abstracts on CD-ROM, 1993-1994.

TAKATA, M. Respiration, ethylene production and ripening of Japanese persimmon fruit harvested at various stages of development. Journal of the Japanese Society for Horticultural Science, v.52, n.1, p.78-84, 1983. Resumo em CAB Abstracts on CD-ROM, 1984-1986.

TAYLOR, J.E. Exotics. In: SEYMOUR, G.B.; TAYLOR, J.E.; TUCKER, G.A. Biochemistry of fruit ripening. London: Chapman \& Hall, 1993. cap.5, p.151186. 
TURK, R. The cold storage of persimmons (Diospyros kaki cv. Fuyu) harvested at different maturities and the effect of different $\mathrm{CO}_{2}$ applications on fruit ripening. Acta Horticulturae, n.343, p.190-194, 1993.

VAN BUREN, J. Fruit phenolics. In: HULME, A.C. The biochemistry of fruits and their products. London: Academic Press, 1970, v.1, p.269-304.

VIDRIH, R.; SIMCIC, M; HRIBAR, J.; PLESTENJAK, A. Astringency removal by high $\mathrm{CO}_{2}$ treatment in persimmon fruit (Diospyros kaki). Acta Horticulturae, n.368, p.652-656, 1994.

WILLS, R.H.H.; LEE, T.H.; GRAHAM, D.; McGLASSON, W.B.; HALL, E.G. Postharvest - An introduction to the physiology and handling of fruit and vegetables. Kensington: New South Wales University Press, 1981. 161p.

WOODS, J.L. Moisture loss from fruits and vegetables. Postharvest News and Information, v.1, n.3, p.195-199, 1990. 